\title{
A COMPARATIVE STUDY OF LOGIT AND ARTIFICIAL NEURAL NETWORKS IN PREDICTING BANKRUPTCY \\ IN THE HOSPITALITY INDUSTRY
}

\author{
By \\ SOO-SEON PARK \\ Bachelor of Science in Hospitality \\ Oklahoma State University \\ Stillwater, Oklahoma \\ 2005 \\ Submitted to the Faculty of the \\ Graduate College of the \\ Oklahoma State University \\ in partial fulfillment of \\ the requirements for \\ the Degree of \\ MASTER OF SCIENCE \\ May, 2008
}




\section{A COMPARATIVE STUDY OF LOGIT AND ARTIFICIAL NEURAL NETWORKS IN PREDICTING BANKRUPTCY IN THE HOSPITALITY INDUSTRY}

Thesis Approved:

\begin{tabular}{c} 
Dr. Murat Hancer \\
\hline Thesis Advisor \\
Dr. Radesh Palakurthi \\
Dr. Sheila Scott-Halsell \\
Dr. A. Gordon Emslie
\end{tabular}




\section{ACKNOWLEDGEMENTS}

First of all, I would like to express much gratitude to my advisor, Dr. Murat Hancer, for his advice and support to complete my Master's thesis. My gratitude is extended to my other committee members, Dr. Radesh Palakurthi and Dr. Sheila ScottHalsell, for their valuable feedback and involvement. I also would like to thank all faculty members in the School of Hotel and Restaurant Administration for providing me such great guidance during my Master's studies.

My special thanks to Dr. Ramesh Sharda who gave me invaluable help and guidance to finish my thesis. His kindness and extensive knowledge about neural networks deserves my deepest respect and sincere gratitude. I also would like to express my sincere appreciation to Dr. Woo-Gon Kim who lead me and inspired me from the beginning of the study. I thank my colleagues, especially, Lisa Hyun-Jung Kim for being a great example as an honorable scholar and for her kind support and advice.

Lastly, I appreciate my family who provided unconditional love throughout my life and I have to express my deepest and truthful love with all my heart. 


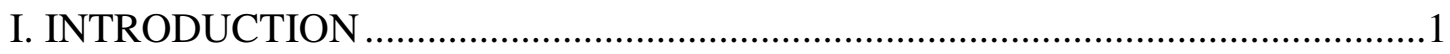

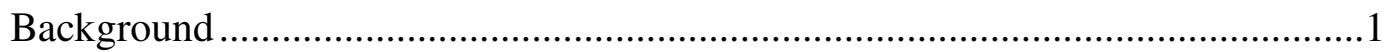

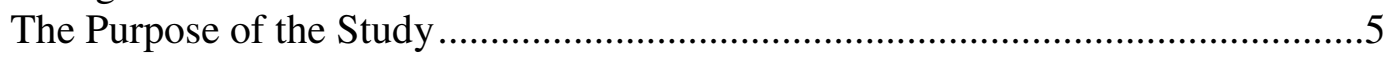

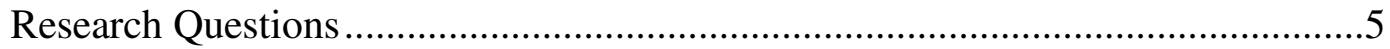

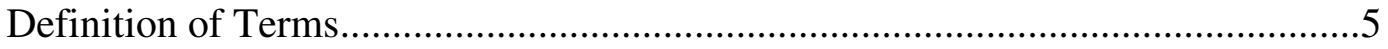

Organization of the Study ……...................................................................6

\section{REVIEW OF LITERATURE}

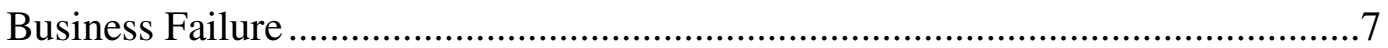

Bankruptcy Prediction Studies in Financial Literature ..........................................

Previous Studies in Artificial Neural Networks..................................................12

Bankruptcy Prediction Studies in the Hospitality Industry....................................16

\section{METHODOLOGY}

Sample and Data Collection............................................................................2

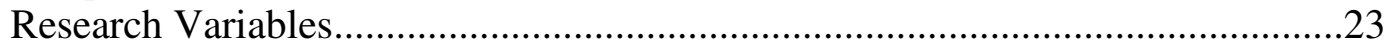

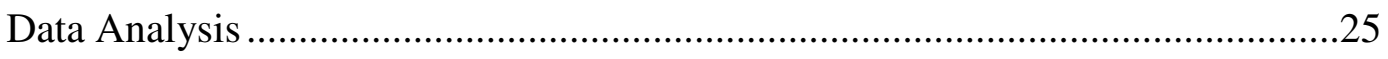

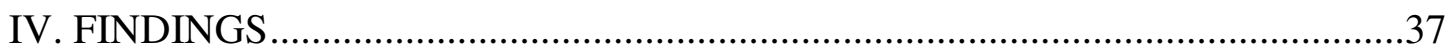

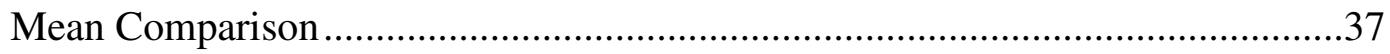

In-Sample Model Construction.............................................................................

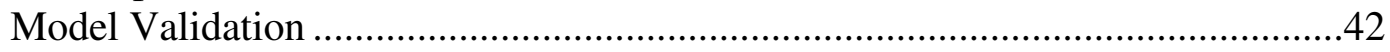

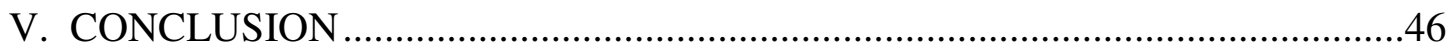

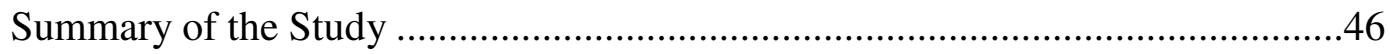

Discussion and Implications .............................................................................

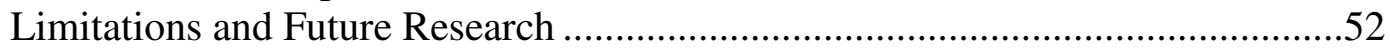




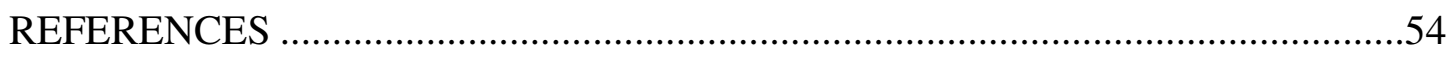

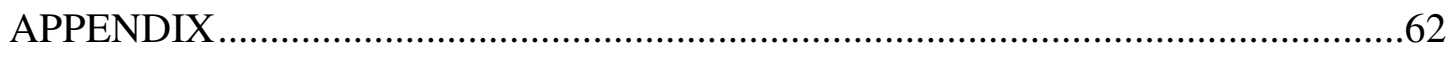

APPENDIX A- SAMPLE FIRMS USED IN MODEL

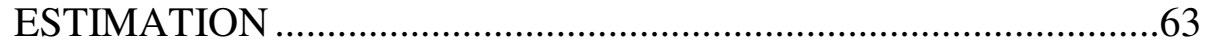

APPENDIX B- HOLDOUT FIRMS USED FOR

PREDICTION ACCURACY TEST …..........................................67 


\section{LIST OF TABLES}

Table $\quad$ Page

1 Bankruptcy by SIC (Standard Industrial Classification Code) .......................8

2 Summary of Bankruptcy Prediction Studies in the Hospitality Industry.........20

3 Comparison of Mean Financial Ratios of the Two Groups .............................38

$4 \quad$ Summary of the Estimated Logit Model.....................................................39

$5 \quad$ Logit Model In-Sample Classification ....................................................41

6 Summary of the Trained Neural Network Model .........................................42

$7 \quad$ Holdout Sample Prediction from Logit Model ............................................43

8 Testing Sample Prediction from Neural Network Model ...............................45 


\section{LIST OF FIGURES}

Figure $\quad$ Page

1 A Network Configuration of Bankruptcy Prediction...................................29

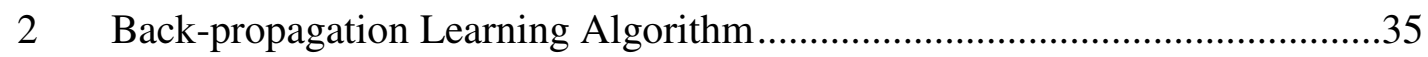




\title{
CHAPTER I
}

\section{INTRODUCTION}

\author{
Background
}

The hospitality business has received scrutiny by many investors and lenders because of its unique risks (Elgonemy, 2002). Historically, the restaurant industry is wellknown for its high failure rate, which prompted many researchers to search for the reasons of restaurants failures (Parsa, Self, Njite, \& King, 2005). As Ernist (2002) stated, more than $30 \%$ of restaurant failed in their first two years of operation. The lodging industry is known to be capital-intensive and highly leveraged, and this can be a burden on managers wishing to obtain the required return and cash flow to meet their obligations.

In addition, the lodging industry is characterized by fluctuating demand. Hotels' profitability is tied to changes in the supply-demand balance. Moreover, overall operating environments for the hospitality industry, during the recession of the 1990s that followed the overbuilding of the 1980s dropped the profitability of many hotel businesses. (Rushmore, 1992).

Fortunately, after 2001, despite lingering fears of terrorist attacks, the lodging industry started to recover. In 2004, room revenue increased $9 \%$ over the previous year and it is achieved by a rise of only 6\% in demand (Smith \& Lesure, 2004, 2005, 2006). 
Considering the combination of growing demand and rises in the average room rate (ADR), this steady growth is still a definite sign of recovery from recession.

In spite of the recovery, the industry still merits attention because it is affected by terrorism, recession, and other changes in its operating environment. Moreover, as the service industry has matured and the market is saturated, competition among hospitality firms has become intense. These characteristics of the hospitality industry can easily cause financial distress for lodging firms and force them to file for bankruptcy (Andrew \& Schmidgall, 1993).

In particular, because a declaration of bankruptcy entails substantial costs including litigation, interest costs, and collection fees, auditors, senior executives, creditors and stockholders prefer early warning. These concerns are closely related to many previous studies that have identified the features of firms' financial stability using firms' financial information.

The use of financial ratios to diagnose a firm's financial condition led to many models designed to predict bankruptcy. Since the introduction of the Altman's Z-Score bankruptcy prediction model (Altman, 1968), a number of prediction models have been developed across industries, regions, and nations. Multivariate Discriminant Analysis (MDA) uses selective financial ratios. It is important to note that MDA is valid only under restrictive assumptions which may result in biased results when violated. This supports the theoretical superiority of the logit model in bankruptcy prediction (Kim \& $\mathrm{Gu}, 2006)$. 
Recently, Artificial Neural Networks (ANNs) have received a great deal of attention in the area of decision support system because of their outstanding ability to forecast and classify events to make a decision (Wilson \& Sharda, 1994). ANNs are inspired by the function of human intelligence. Over the last half century, numerous researchers have studied ANNs. ANNs' ability to forecast and predict has been a serious contender for conventional statistical applications. In fact, several studies have found that ANNs are more accurate than statistical models such as Multivariate Discriminant Analysis (MDA) and logit models in accuracy rate (Lee, Booth, \& Alam, 2005; Tam, 1991) and ANNs are free of restrictive statistical assumptions (Aminian, Suarez, Aminian, \& Walz, 2006).

Despite many attempts to predict bankruptcy in the hospitality industry, there is still a great deal of room for methodological improvement. Harris and Brown (1998) stated that a more in-depth approach and sophisticated methodology are encouraged among researchers. A more in-depth approach and sophisticated methodology are to embrace the nature of the hospitality industry and draw more meaningful conclusions from research. In addition, the study by Chava and Jarrow (2004) concluded that industry groupings significantly affected in forecasting firms' bankruptcy because firms in the same industry group are assumed to be under the same legal, political, and economic influences. However, only a few empirical studies of bankruptcy prediction have focused on the hospitality industry, with its complexity and vulnerability. Furthermore, there is a dearth of bankruptcy prediction studies of the hospitality industry that have used ANNs. 
Therefore, this study will use ANNs to predict bankruptcy among hospitality firms. This study will compare the performance of ANNs in predicting hospitality firms' bankruptcy to the more conventional statistical logit model. 
The Purpose of the Study

The purpose of this study is to compare the accuracy of an Artificial Neural Networks to that of a logit model in predicting hospitality firms' bankruptcy.

\section{Research Questions}

The research questions are as follows:

Research Question 1: Does an Artificial Neural Networks outperform Logit, a conventional statistical technique, in predicting a hospitality firm's bankruptcy?

Research Question 2: What financial ratios significantly predict the classification of hospitality firms as bankrupt or non-bankrupt?

\section{Definition of Terms}

1. Bankruptcy: This is a legal status, one that involves many parties in litigation and requires a petition in federal court for filing for protection under either Chapter 7 of the legal code, which entails reorganization of its debts, or Chapter 11, which includes liquidation of its assets (Keown, Martin, Petty, \& Scott, 1982).

2. Hospitality Industry: This consists of a variety of service industries including, lodging, food service, casinos, and tourism (Angelo \& Vladimir, 2001). 
3. Artificial Neural Networks: These are mathematical models based on biological neural networks of human brain. ANNs are configured for specific tasks such as pattern recognition or data classifications (Shah \& Murtaza, 2000).

4. Logit Model: This statistical model is used to predict the probability of occurrence of certain events occuring. It is also referred to as logistic regression (Ohlson, 1980).

\section{Organization of the Study}

This investigation of the hospitality bankruptcy prediction model consists of five chapters. Chapter II will summarize the previous literature on business failure. It has four sections: studies of business failure, bankruptcy-predicting studies in the financial literature, studies of artificial neural networks, and bankruptcy-predicting studies in the hospitality industry. Chapter III provides the research methodology of the study: data collection procedure, logistic regression and artificial neural networks, and research variables. Chapter IV presents the empirical results. Chapter V discusses the implications and limitations of the study. 


\title{
CHAPTER II
}

\section{REVIEW OF LITERATURE}

\author{
Business Failure
}

There is no clear and universally-accepted definition of business failure. The term 'business failure' is used to describe a firm's financial health study (Dimitras, Zanakis, \& Zopounidis, 1996). Altman (1993) introduced three types of business failure: economic failure, insolvency, and bankruptcy. According to his study, 'economic failure' is a situation in which a firm has a lower return on investment than required level based on industry standards. 'Insolvency' is a situation in which a lack of liquidity prevents a firm from meeting its financial obligations. 'Bankruptcy' is a legal status that involves litigation and requires a petition in federal court.

Obviously, business failure threatens a firm's survival. It can harm its owners, managers, shareholders, employees, suppliers, clients, and even the government. Additional burdens of business failure are the high legal and collection fees that accompany bankruptcy. More importantly, business failures hurt society and the country's economy. For these reasons, many researchers and practitioners are interested in predicting business failure. Table 1 summarizes the number of companies that filed for bankruptcy, grouped by industry classification in the U.S, from 1962 to 1999. It shows 
that the manufacturing industry has the highest number of bankruptcy filings, followed by the retail trade and service industries.

Table 1. Bankruptcy by SIC (Standard Industrial Classification Code)

\begin{tabular}{ccc}
\hline SIC Code & Industry Name & Number (\%) of Bankruptcies \\
\hline$<1000$ & $\begin{array}{c}\text { Agriculture, Forestry and } \\
\text { Fisheries }\end{array}$ & $30(2.06 \%)$ \\
\hline 1000 to less than 1500 & Mineral Industries & $116(7.96 \%)$ \\
\hline 1500 to less than 1800 & Construction Industries & $27(1.85 \%)$ \\
\hline 2000 to less than 4000 & Manufacturing & $545(37.38 \%)$ \\
\hline 4000 to less than 5000 & $\begin{array}{c}\text { Transportation, Communications, } \\
\text { and Utilities }\end{array}$ & $116(7.96 \%)$ \\
\hline 5000 to less than 5200 & Wholesale Trade & $69(4.73 \%)$ \\
\hline 5200 to less than 6000 & Retail Trade & $211(14.47 \%)$ \\
\hline 6000 to less than 6800 & $\begin{array}{c}\text { Finance, Insurance, and Real } \\
\text { Estate }\end{array}$ & $160(10.97 \%)$ \\
\hline 7000 to less than 8900 & Service Industries & $180(12.35 \%)$ \\
\hline 9100 to less than 10000 & Public Administration & $0(0 \%)$ \\
\hline Total number of bankruptcy & $1461(100 \%)$ \\
\hline $\begin{array}{l}\text { Source }: \text { Chava, S., \& Jarrow, R. (2004). Bankruptcy prediction with industry effects. Review of Finance, } \\
8,37-569 .\end{array}$ &
\end{tabular}




\section{Bankruptcy Prediction Studies in Financial Literature}

Financial ratios are a typical method of assessing both firms' present and future financial performance, since the figures on balance sheets and income statements reflect a firm's financial status. One of the primary uses of financial ratios is the prediction of bankruptcy by using these ratios as variables. Beaver (1968) employed univariate analysis to estimate the predictive power of financial ratios on bankruptcy. The author tested six groups of ratios: cash flow, debt to total asset, net income, liquid assets to total asset, liquid assets to current debt, and turnover; the conclusion is that the combination of more than one ratio will give a researcher better predictability for further study (Beaver, 1968).

After Beaver's study of bankruptcy prediction utilizing financial ratios, Altman (1968) introduced the Altman Z score model, using Multiple Discriminant Analysis (MDA). Many researchers across disciplines have come to rely on MDA (Blum, 1974; Edmister, 1972). MDA uses a set of predictor variables to determine whether dependent variables indicate either bankrupt or non-bankrupt dichotomously. Altman chose 33 variables in the study to predict bankruptcy. After employing the step-wise procedure, to determine the extent of each variable's contribution, five ratios remained, which he considered to be significant predictors. The author cited limitations of the study in terms of industry scope and firm size, but his use of Multiple Discriminant makes this study the standard by which other models are measured (Altman, 1968). 
Edmister (1972) was the first to examine the sizes of the firms being tested. The primary contribution of the study is the use of industry averages to generate standardized ratios. Blum (1974) broadened the scope of the study criteria by using a different indication to determine the population of the companies to be studied. The author looked beyond firms that had filed for bankruptcy in legal terms and included companies that made explicit agreements with creditors to reduce their debts. By doing this, the author obtained a data set that consisted of 115 failed and 115 non-failed firms. Moreover, the study grouped 12 ratios in terms of liquidity, profitability and variability. The inclusion of measures of variability differentiated this study from previous studies. Blum found a 93-95\% predictive accuracy for the model in the first year prior to failure and cash flow/total debt as the best predictor, conforming Beaver's (1968) study.

Ohlson (1980) criticized prior studies that had been conducted using MDA technique because of its assumptions. With the MDA, the distributional properties of ratios are assumed to be normally distributed and the samples of companies are assumed to be randomly selected. However, financial figures are often not normally distributed because financial figures are skewed in the positive direction. This is due, in part, to the fact that a company may not necessarily be limited by the amount of money it can make, but by the amount of money it can lose. Violations of these assumptions can lead to inaccurate predictions. To overcome these pitfalls in collecting samples and variables for bankruptcy prediction models, the author used a logit analysis model and selected a simple data set. Logit analysis is a multivariate technique which uses all predictor 
variables simultaneously, but it does not carry the same assumptions of the MDA techniques. Ohlson's study is valuable because he conducted a logit model study whose theoretical soundness was supported by future researchers.

Following Ohlson's business failure study with a logit model, researchers conducted multiple studies to improve its classification accuracy using a logit model. Zavgren (1985) developed a measure, using a logit model with seven financial ratios, and tested its prediction capability for up to five years prior to bankruptcy. Hamer (1983) compared MDA to the logit technique using different data sets, and concluded that the two models were comparable in assessing the probability of failure. Lo (1986) studied corporate bankruptcies, comparing the logit model to MDA, and concluded that the logit model was more robust than MDA. Darayseh, Waples, and Tsoukalas (2003) conducted a study using a logit model to predict corporate bankruptcy and obtained $88 \%$ accuracy for in-sample and holdout sample tests. Chi and Tang (2006) collected a sample of firms in seven Asia-Pacific capital markets to exam trade credit risk using a logit model. This study took a closer look into misclassification costs associated with cutoff value determination. Tseng and Lin (2005) used a quadratic interval logit model in attempt to achieve more accurate results by reducing a fuzzy relationship with explanatory independent variables and binary dependent variables. 


\section{Previous Studies of Artificial Neural Networks}

The formal study of Artificial Neural Network (ANNs) was initiated by McCulloch and Pitts (1943). Inspired by biological networks and observations in the human brain, they built a simple binary neural network model using a number of interconnected neurons linked together. Since McCulloch and Pitts (1943) introduced their ANNs model, ANNs have received a great deal of attention as the theoretical foundations of building learning systems in the late 1950s and early 1960s (Sharda \& Wang, 1996; Tam, 1991). However, Minsky and Paper's (1969) criticism of the functional limitations of its single-layer network led to a decline in the amount of research.

The stream of neural network studies was resuscitated 20 years ago with recent advances in neural networking topologies, activation function, and new learning algorithms such as back-propagation, radial basis functions networks (RBFs), and learning systems. Different ANNs' learning algorithms and topologies have been extensively studied and applied to various predicting/classifying tasks. For instance, ANNs have shown that a model can be trained to predict probabilities of occurrences, classifying events such as bankruptcy prediction, customer targeting, credit-risk evaluation, and even human resource practice analysis (Baesens, Setiono, Mues, \& Vanthienen, 2003; Coats \& Fant, 1993; Kim, Street, Russel, \& Menczer, 2005; Stavrou, Charalambous, \& Spiliotis, 2007). 
In both academic and industrial tourism research, ANNs have recently received extensive attention due to their superiority over traditional statistical techniques in forecasting consumer behavior and demand in the tourism industry. This is because the nature of the tourism industry makes it particularly susceptible to such factors (Palmer, Montono, Sese, 2006; Pattie \& Snyder, 1996; Wang, 2004). De Carvalho, Dougherty, Fowkes, and Wardman (1998) conducted a comparative study of logit and ANNs in forecasting travel demand. The study used three sets of data: synthetic data, which fulfills the logit assumptions; synthetic data, which violates the logit assumptions, and real data. The study results revealed that back-propagation neural networks achieved better accuracy when dealing with synthetic data, which breaches the logit assumptions. Of more interest is the discovery that same is true of real data. This indicates that ANNs do not require assumptions which are often violated by real data. Law and Au (1999) built a neural network model to forecast Japanese demand for travel to Hong Kong. The authors compared results derived from five different methods: neural networks, multiple regression, naïve, moving average, and exponential smoothing. The neural network model was supervised feed-forward perception consisting of five neurons in the input layers and a single neuron in the output layer. The study concluded that neural networks hold the superior forecasting efficiency than that of rest of four techniques. The authors pointed out that, though the neural network showed the best forecasting efficiency, the adequate techniques should be employed in certain situations to optimize the efficacy of analysis. Tsaur, Chiu, and Huang (2002) employed two prediction techniques: a neural 
network model and logistic regression to determine attributes of guest loyalty to international tourist hotels. The model adopted eight neurons, each representing responsiveness, tangibility, meal service, location, reliability, empathy, reputation, and business service. The results showed that the neural network model achieved more satisfactory model-fitting in determining attributes of guest loyalty to international hotels. Cho (2003) utilized three time-series forecasting techniques: exponential smoothing, Auto-Regressive Integrated Moving Average (ARIMA), and Neural Networks to forecast visitor arrivals to Hong Kong from six countries (USA, Japan, Taiwan, Korea, the UK, and Singapore). The results were compared to determine the best performing techniques. The results revealed that the neural networks outperformed the other two methods, especially when dealing with the less obvious patterns of Korean and Japanese visitors.

In bankruptcy prediction studies, the first attempt to use neural networks was made by Odom and Sharda (1990). They compared the performance of neural networks to Altman's MDA model using the five financial ratios that Altman had used in 1968. The empirical results demonstrated that neural networks outperformed MDA with regard to prediction accuracy and model robustness. Following the study by Odom and Sharda (1990), additional studies were conducted to investigate the effectiveness of neural network. For instance, Salchenberger, Cinar, and Lash (1992) used a network for the analysis of the bankruptcy of savings and loan institutions and showed that the neural networks outperformed logit models across different lead times. Tam and Kiang (1992) intended to prove the superiority of neural network in predicting bankruptcy. They 
compared several methodologies including MDA, logistic regression, $k$-nearest neighbor, and a machine learning method of a decision tree. This study concluded that neural networks showed better performance than any other techniques in predicting bankruptcy status.

Following previous ANNs studies, Wilson and Sharda (1994) conducted an exploratory study which compared predictive capability of neural networks to that of MDA. This study utilized the concept of Monte Carlo resampling techniques, in order to obtain better predictive accuracy, by reducing the impact of base rate on the performance of prediction techniques. The authors generated three composition levels of bankrupt and non-bankrupt firms in the training set and three composition levels of bankrupt and nonbankrupt levels in the testing set, generating nine different outputs. The empirical results revealed that neural network demonstrated significantly higher predictive accuracy than MDA. In the study by Boritz and Kennedy (1995), the proportions of bankrupt firms and non-bankrupt firms both in training and testing sets, were also a matter of concern. It demonstrated that different proportions of bankrupt firms and non-bankrupt firms in the training sample and testing samples affected prediction accuracy. They also found that different neural network approaches have varying effects on the levels of Type-I and Type-II error, which may result in misclassification of firms.

While recent studies focus on the relative performance of neural network over conventional statistical techniques, the study by Altman, Marco, and Varetto (1994) showed that the performance of neural network and other statistic techniques were 
comparable with regard to the degree of accuracy. Lee et al. (2005) examined on relative performances between supervised and unsupervised neural network models. This study used a back-propagation algorithm and Kohonen self-organizing feature map as a representative model of both supervised and unsupervised neural network models. The study revealed that supervised back-propagation is better when a target vector was available. During past decades, research in many fields has been conducted using neural networks by many researchers in various fields. Especially, great improvements in predicting and classifying tasks such as bankruptcy prediction have contributed to neural networks' sophisticated algorithms and advanced modeling systems (Belhadjali \& Whaley, 2004).

\section{Bankruptcy Prediction Studies in the Hospitality Industry}

Gao (1999) analyzed firms' bankruptcy from both microeconomic and macroeconomic perspectives. From a microeconomic view, the study tested the multiple discriminant model with 25 hospitality firms (eight lodging companies and seventeen restaurant companies). Out of 17 financial variable tested, four ratios: total equity to total assets, retained earnings to total assets, EBIT to total liabilities, and sales to fixed assets were selected based on the result of stepwise procedure. The model incorporating the four ratios achieved an accuracy rate of $92 \%$ one year prior to bankruptcy and an $83 \%$ accuracy rate two years in advance. From macroeconomic perspective of the study, the 
result validated that change of real gross state product and change of disposable personal income have a significant impact on lodging firms' failure.

Gu and Gao (1999) also conducted a bankruptcy prediction study focusing on the hospitality industry. The study sample consisted of 14 hospitality companies and estimated a multivariate discriminant model to predict hospitality firm bankruptcy. The model reached $93 \%$ accuracy with in-sample firms in one year prior to bankruptcy.

Patterson (2001) analyzed bankruptcy in the casino industry. In his study, he developed a theoretical model based on the casino industry's unique characteristics. His model utilized 12 variables that differed significantly from those used in other studies: marketing costs/total revenue, net income/total assets, total revenues/total assets, operating margin, payroll costs/total assets, percent changes in marketing costs/total revenues ratio, percent changes in cash balance/total liabilities ratio, percent change in total revenues/total liabilities ratio, percent change in operating margin ratio, percent change in operating margin ratio, percent change in payroll costs/total revenues ratio, and percent change in payroll costs/total assets ratio. The results of a discriminant analysis generated a model using the 12 variables, showing an in-sample classification accuracy of $100 \%$ and a $92.3 \%$ accuracy rate with a holdout sample. This was significantly higher accuracy than that found in many previous studies.

Gu (2002) also studied restaurant firms' bankruptcy with a multiple discriminant model. The study selected two variables with the forward-stepwise procedure, which included total liabilities to total assets and earnings before interest and tax to total 
liabilities out of 12 initial variables. The model achieved a $92 \%$ accuracy rate in predicting firms' bankruptcy one year prior to the occurrences. The study suggested that more profitable operation policies and sound debt-financing strategies are crucial to keep companies from going bankrupt.

Kroeze (2005) investigated industry-specific bankruptcy. She used a modified Altman's Z-score model to predict bankruptcy in airline corporations. The study sample consisted of 16 airline companies. About three to four years of financial information for each sample company was collected and analyzed. This study achieved overall $62 \%$ of prediction accuracy when it applied Altman's Z-score model. The study developed a Kroeze Model by modifying Altman's Z score model. By applying the modified Kroeze Model, the study achieved overall $62 \%$ of prediction accuracy and found that retained earnings to total assets was the most significant financial variable in detecting an occurrence of bankruptcy. Despite the small sample size, the study demonstrated that the two models applied to the study were able to detect occurrences of bankruptcy up to four years before the events.

Kim (2006) made a first attempt to apply logistic regression to predict bankruptcy in the hospitality industry. He constructed the sample with 16 bankrupt firms and 16 nonbankrupt firms and achieved $84 \%$ and $91 \%$ accuracy in predicting the bankruptcy status of firms one year and two years prior to bankruptcy, respectively. This study recommended that future research should consider external impacts such as geographic 
diversification and market segmentation, into account for more sophisticated analysis and accurate examination.

To find the strengths of both the multiple discriminant model and the logit model in predicting bankruptcy, Kim and Gu (2006) compared the two models using the same set of data that Gu's (2002) study had previously used. They employed a logit forward stepwise statistical procedure and selected two financial variables, total liabilities to total assets and EBIT to total liabilities from 12 candidate variables. The result of logistic regression showed that the model correctly classified $93 \%$ of sample firms, while the previous study achieved a $92 \%$ accuracy rate in classifying bankruptcy firms. The results of the study showed that both techniques have comparable ability to predict bankruptcy. However, the study concluded that the logit model was more preferable because of its theoretical soundness and that it does not require the statistical assumptions with which the MDA technique associates. Table 2 summarizes bankruptcy prediction studies in the hospitality industry. 
Table 2. Summary of Bankruptcy Prediction Studies in the Hospitality Industry

\begin{tabular}{|c|c|c|c|}
\hline Researcher(s) (Year) & Title & Sample used & Methodology(ies) \\
\hline Gao (1999) & $\begin{array}{l}\text { Study of business failure } \\
\text { in the hospitality } \\
\text { industry from both } \\
\text { microeconomic and } \\
\text { macroeconomic } \\
\text { perspectives }\end{array}$ & $\begin{array}{l}\text { Eight lodging } \\
\text { companies } \\
17 \text { restaurant } \\
\text { companies }\end{array}$ & $\begin{array}{l}\text { MDA (Multivariate } \\
\text { Discriminant } \\
\text { Analysis) }\end{array}$ \\
\hline Gu \& Gao (1999) & $\begin{array}{l}\text { A multivariate model for } \\
\text { predicting business } \\
\text { failures of hospitality } \\
\text { firms }\end{array}$ & $\begin{array}{l}10 \text { restaurants } \\
\text { companies } \\
\text { Four lodging } \\
\text { companies }\end{array}$ & $\begin{array}{l}\text { MDA (Multivariate } \\
\text { Discriminant } \\
\text { Analysis) }\end{array}$ \\
\hline Patterson (2001) & $\begin{array}{l}\text { Bankruptcy prediction: } \\
\text { A model for the casino } \\
\text { industry }\end{array}$ & Casinos* & $\begin{array}{l}\text { MDA (Multivariate } \\
\text { Discriminant } \\
\text { Analysis) }\end{array}$ \\
\hline Gu (2002) & $\begin{array}{l}\text { Analyzing bankruptcy in } \\
\text { the restaurant industry: } \\
\text { A multiple discriminant } \\
\text { model }\end{array}$ & $\begin{array}{l}18 \text { restaurant } \\
\text { companies }\end{array}$ & $\begin{array}{l}\text { MDA (Multivariate } \\
\text { Discriminant } \\
\text { Analysis) }\end{array}$ \\
\hline Kroeze (2005) & $\begin{array}{l}\text { Predicting airline } \\
\text { corporate bankruptcies } \\
\text { using a modified Altman } \\
\text { Z-Score model }\end{array}$ & 11 airline companies & $\begin{array}{l}\text { MDA (Multivariate } \\
\text { Discriminant } \\
\text { Analysis) }\end{array}$ \\
\hline Kim (2006) & $\begin{array}{l}\text { Logistic regression } \\
\text { analysis for predicting } \\
\text { bankruptcy in the } \\
\text { hospitality industry }\end{array}$ & $\begin{array}{l}10 \text { restaurant } \\
\text { companies } \\
\text { Six lodging companies }\end{array}$ & Logistic Regression \\
\hline Kim \& Gu (2006) & $\begin{array}{l}\text { Predicting restaurant } \\
\text { bankruptcy: A logit } \\
\text { model in comparison } \\
\text { with a discriminant } \\
\text { model }\end{array}$ & $\begin{array}{l}18 \text { restaurant } \\
\text { companies }\end{array}$ & $\begin{array}{l}\text { Logistic } \\
\text { Regression/MDA } \\
\text { (Multivariate } \\
\text { Discriminant } \\
\text { Analysis) }\end{array}$ \\
\hline
\end{tabular}

Note: *Detailed information of the sample used in the study kept confidential. 


\title{
CHAPTER III
}

\section{METHODOLOGY}

\author{
Sample and Data Collection
}

The sample data collection for the bankruptcy prediction model required a clear definition of failure and specification of the population. In this study, the sample firms included were selected solely based on the legal status of 'bankruptcy'. The failed companies included in the study had already filed for Chapter 11 bankruptcy. The list of bankrupt firms was available from the New Generation Research Inc.'s Bankruptcy Database from 1992 to 2007 . Though a shorter period is more desirable, with respect to reducing economic effects on sample firms' bankruptcy occurrences, the 15-year sample period was necessary in order to obtain an acceptable sample size for an analysis. Moreover, since the purpose of study is to compare the two methodologies, biases caused by external aspects can be ignored as long as the equal condition is provided. From the list of bankrupt firms, publicly-traded hospitality firms represented by the primary Standard Industrial Classification (SIC) code 5812 (Eating and Drinking Places), 7011 (Hotels and Motels) and 7990 (Services-Miscellaneous Amusement \& Recreation), were included for the study. One hundred and twenty-eight firms were selected, 24 bankrupt firms and 104 non-bankrupt firms. 
The primary purpose of the study is to compare the accuracy of an Artificial Neural Networks to that of a logit model in predicting hospitality firms' bankruptcy. Therefore, the same collection of sample companies was used for both neural network and logit analysis. In neural network analysis, out of 128 companies, 104 companies were used to train the neural network (also, referred to training phase) and 24 companies were used for testing phase. Similarly, the same proportion of sample was used for model estimation and holdout sample test to validate the estimated model created by logit analysis. A list of selected firms in the sample of this study is presented in Appendix A. After model estimation, in an attempt to test prediction accuracy, ten firms excluded for model estimation were used to test the model's predictive power for both ANNs model and a logit model. The holdout sample used in the model accuracy test is listed in Appendix B. In spite of attempts to match the number of firms in the holdout sample with the number of firms in the estimation sample, a lack of financial information made this impossible. For model estimation, financial information of sample firms such as total assets, cash flows, and net income was collected from Standard \& Poor's Compustat database. Financial information used for bankrupt firms was from the last financial statement issued before the firms filed for bankruptcy. Thus, the bankruptcy prediction was made about one year prior to bankruptcy. 


\section{Research Variables}

For the purpose of this study, 18 variables were examined as potential predictors of business failure. 18 financial indicators such as current ratio, ROA (Return on asset, profit margin of sample firms were used as research variables. These variables were determined on the basis of references to key attributes which prior studies found as important indicators of bankruptcy (Ferner \& Hamilton, 1987; Kim, 2006).

Financial ratios are generally classified into several groups based on the information that each financial ratio represents (Andrew \& Schmidgall, 1993). The variables used in the study have been grouped into five categories: liquidity, solvency, leverage, profitability, and efficiency.

Liquidity ratios measure a firm's ability to meet its short-term obligations, that is, the ability of a firm to pay short-term expenses. The higher the value of the ratio is the more margins of financial securities that a company reserves enough liquidity to meet its obligation. A level of liquidity of a firm is very important to evaluate firms' financial position. In this study, the current ratio, quick (acid) ratio, and working capital to total assets ratio were selected for model estimation.

Solvency ratios measure a firm's ability to meet its long-term obligations, and solvency ratios indicate a firm's degree of debt financing. When a company is insolvent, its chance of going bankrupt increases drastically. In this study, solvency was measured 
by liabilities to net worth and debt to earning before interest, tax, and depreciation and amortization (EBITDA).

Leverage ratio measures a level of money that investors or businesses borrowed from external resources to maximize shareholder's return. It shows the use of debt instead of equity to maximize a firm's speculative capacity. In this study, debt to market value of equity and tangible financial leverage were used to weigh firms' leverage.

The profitability ratios are important since they reflect the management team's operational effectiveness. The main concern of owners and investors is building their wealth, which is highly dependent on firms' profitability from operations. Therefore, the primary purpose of operation is to generate a profit. $\mathrm{Gu}$ (2002) indicated that unprofitable firms have a higher likelihood of going bankrupt. In this study, profitability was measured by five variables: gross profit margin, net profit margin, net income to the number of employees, return on assets (ROA), and return on sales (ROS).

Operating efficiency is a firm's ability to generate sales revenue by using its resources as efficiently as possible. Four ratios were used in the study to measure firms' operating efficiency: total assets turnover and fixed assets turnover, earning before interest, tax, and depreciation and amortization (EBITDA) to total assets, and earning before interest and tax to current assets (EBIT) were used to measure a firm's ability to maximize its revenue with a given amount of resources. Furthermore, additional two values from income statement; net income and EBITDA were selected as research variables as well as 16 ratios. 


\section{Data Analysis}

In order to compare performance of two methodologies in classifying firms' bankruptcy, collected data were analyzed in two different ways. Empirical results of each analysis were the subject of comparison.

First, the data was entered into the Statistical Package for Social Sciences 15.0, (SPSS), for an independent t-test for mean comparison and logistic regression analysis. Prior to conducting the logistic analysis, the independent t-test was utilized to identify whether there was a difference in the mean value of each variable between bankrupt and non-bankrupt firms. T-values and p-values of each comparison were investigated. After the t-tests, logistic regression analysis was employed. The main advantage of this method is that no assumptions are necessary regarding the distributional properties of the predictors. In addition, it creates a non-linear transformation of the predictor variables, which reduces the impact of outliers. In estimating the logit model for predicting bankruptcy, dependent variable 1 was assigned to bankrupt firms and 0 was assigned to non-bankrupt firms. In logit analysis, the 'odds' of dichotomous outcomes are related to a set of independent variables. The odds were defined as, "the ratio of probabilities of bankruptcy to probability of non-bankruptcy," in turn, $p /(1-p)$, where $p$ is probability of bankruptcy occurrence. It was expressed in logit form (1): 


$$
\log [P(x) /(1-P(x))]=\beta_{0}+\beta_{1} X_{1}+\beta_{2} X_{2}+\cdots+\beta_{i} X_{i}
$$

Where,

$P(x)=$ Probability of the bankruptcy occurrence

$\beta_{0}=$ the intercept term

$\beta_{1}-\beta_{i}=$ the $\beta$ coefficient associated with the corresponding explanatory variable $X$ $X_{1}-X_{i}=$ the financial ratios

Several studies have attempted to find financial ratios as predictor variables which have a significant impact on determining firms' bankruptcy (Barniv, Agarwal, \& Leach, 2002; Nam \& Jinn, 2000). According to Theodossiou (1991), selecting financial ratios as independent variables can be onerous for researchers because representations of financial ratios are not necessarily associated with statistical significance in a model. Therefore, this study employed the forward stepwise procedure to select the variables for inclusion in a logit model among 18 candidate variables.

The dependent variable is the natural logarithm of the odds, which can be interpreted as the predicted probability (Hosmer \& Lemeshow, 1989; Pampel, 2000). The probability of bankruptcy occurrence lies between 0 and 1 and is expressed in a dichotomy.

The natural logarithm of the odds can be interpreted according to Equation (2): 


$$
P(x)=\frac{1}{e^{-\left(\beta_{0}+\beta_{1} x_{1}+\beta_{2} x_{2}+\ldots+\beta_{i} x_{i}\right)}}
$$

Where,

$\mathrm{e}=$ the base of the natural logarithm

$y=\beta_{0}+\beta_{1} X_{1}+\beta_{2} X_{2}+\cdots+\beta_{i} X_{i}$

The probability of bankruptcy occurrence was calculated according to Equation (2) and the sample firms were classified into either a bankrupt or a non-bankrupt group based on its predicted probability of bankruptcy.

Second, collected data were imported in SPSS Clementine 11.0 for neural network analysis. Artificial Neural Networks (ANNs) are mathematical representations or computational models mimicking the neurobiological networks of the human brain function. The human brain's bewildering capabilities to process information, learn, and solve problems inspired researchers to construct a model that resembled its structure (Tam \& Kiang, 1992).

ANNs are dynamic systems that consist of multiple parallel layers: an input layer, a hidden layer, and an output layers. Each layer is composed of interconnected interacting groups of artificial neurons. These neurons receive stimuli from the external and internal environment and exchange information by releasing neurotransmitters to the neighboring neurons (Shah \& Murtaza, 2000). Repetition of the interacting process occurs during the training phase until the system recognizes a pattern of received information. In the 
current study, 18 financial ratios' of hospitality firms served as the external stimuli to train the model.

ANNs are designed to emulate the human brain's pattern recognition function through processing multiple inputs (Anandarajan, Lee, \& Anandarajan, 2001). As a biological network produces a response in self-adaptive neurobiological connections and interactions among neurons, input-output mapping functions of ANNs are commanded according to computational algorithm designed to alter the weights of connections of homogeneous units. Most ANN models correspond to a mathematical function represented by $\mathbf{f}: \mathbf{X} \rightarrow \mathbf{Y}$ and each type of ANNs model has each function of X. Figure 1 illustrates a neural network model used in this study for bankruptcy prediction. The neural network model used in this study is MLP (Multi-Layer Perceptron) network, multi-layer consisting an input layer, hidden layer, and output layer and feed-forwarding model meaning that data is fed forward from the input nodes to the output nodes without ever looping back on itself. An input vector in the input layer, $\mathrm{Xi}=\left(\chi_{\mathrm{i} 11}, \chi_{\mathrm{i} 2}, \chi_{\mathrm{i} 3}, \chi_{\mathrm{i} 4}, \ldots\right.$, $\chi_{\text {i18), }}$, represents each financial ratios listed in the previous section. 
Figure 1. A Network Configuration of Bankruptcy Prediction

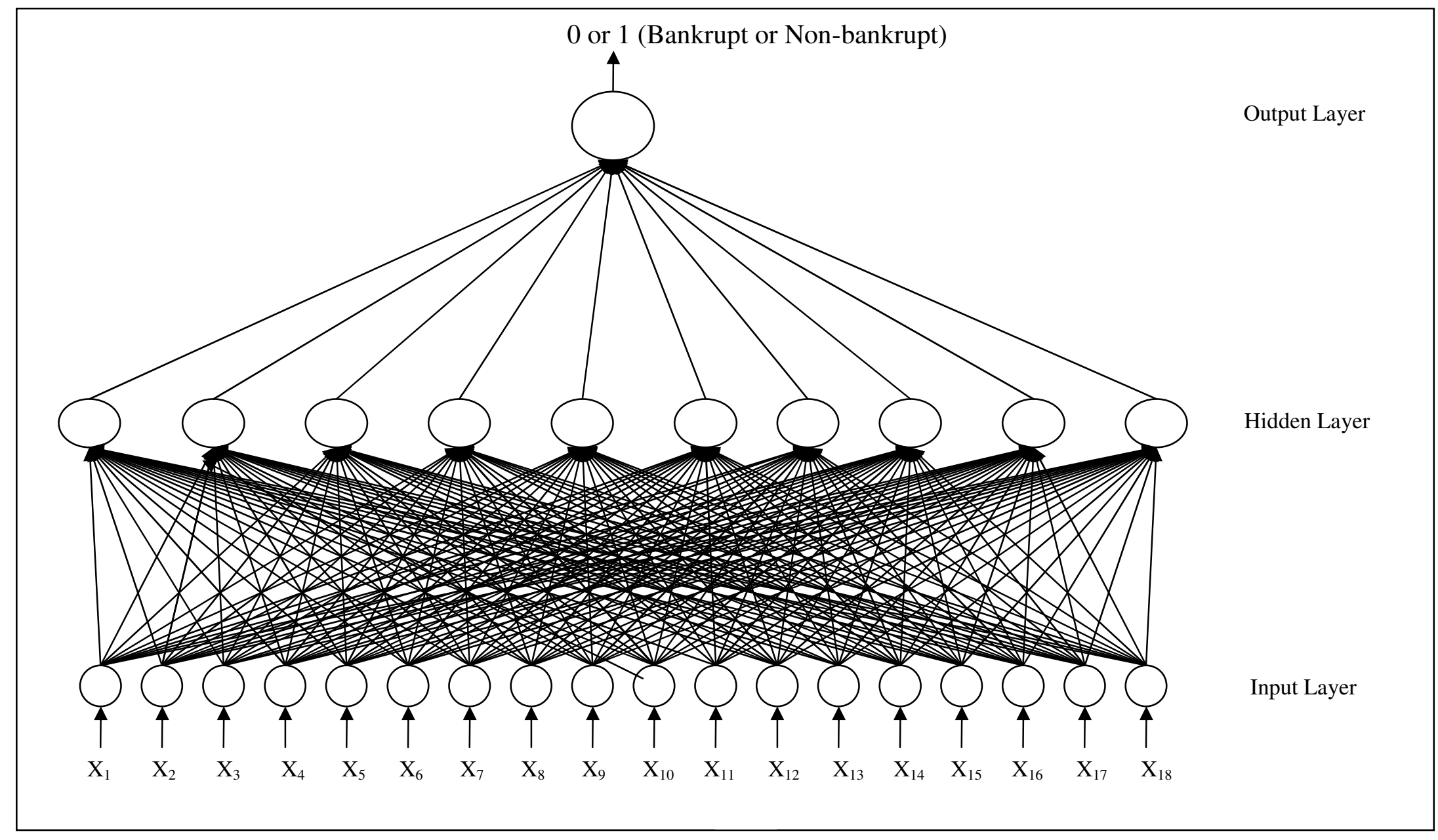

Note: $X_{1}=$ gross profit margin, $X_{2}=$ EBITDA, $X_{3}=$ net income, $X_{4}=$ debt to EBITDA, $X_{5}=$ liabilities to net worth, $X_{6}=$ EBITDA to total assets, $X_{7}=$ debt to market value of equity, $\mathrm{X}_{8}=$ current ratio, $\mathrm{X}_{9}=$ quick ratio, $\mathrm{X}_{10}=$ fixed asset turnover, $\mathrm{X}_{11}=$ net profit margin, $\mathrm{X}_{12}=$ total asset turnover, $\mathrm{X}_{13}=$ tangible asset leverage, $\mathrm{X}_{14}=$ working capital to total asset, $\mathrm{X}_{15}=$ EBIT to total current assets, $\mathrm{X}_{16}=$ net income to total employees, $\mathrm{X}_{17}=$ ROA, $\mathrm{X}_{18}=$ ROS. 
In this study, the SPSS Clementine 11.0 neural network software package was used for data analysis. This software implements back propagation learning algorithm to train a neural network model. Back propagation algorithm refers to a method training a neural network model by adjusting each node's weights until it converges to desired value. Since the desired value is provided to the model while it is trained, it is referred to a supervised learning technique and it is designed to train feed-forward network (Anandarajan et al., 2001, Tam, 1991; Tam \& Kiang, 1992).

\section{Back-propagation Training Algorithm}

In the training phase, an input vector $X_{i}=\left(\chi_{i 1}, \chi_{i 2,}, \chi_{i 3}, \chi_{i 4}, \ldots, \chi_{i 18}\right)$, the numerical values of 18 financial ratios with varying weights associated with function $f$, generates intermediate y values, which can be defined as:

$$
f(w x)=w x
$$

In this current study, 18 financial variables served as the input nodes and each input node associates with varying weights. Inputs nodes in the input layer are connected to the hidden nodes in the hidden layer. In the hidden layer, each of these weights is adjusted through a number of iteration until the neural network model finds the best fit for the given answers. Expanding the simple equation to more than one variable along with the number of input nodes $f(w x)$ becomes:

$$
f(w x)=\sum_{i=1}^{n} w_{i} x_{i}
$$


From the equation above, the sum of these weighted inputs can be derived. The sum of weighted input (a), which can be presented as intermediate $y$, is transformed to the sigmoid function with respect to the issue of discontinuity. By passing through the sigmoid function, the outcome can range between 0 and 1 .

$$
F(y)=\frac{1}{1+e^{-\alpha y}}
$$

In the equation, the parameter $\alpha$ is called Sigmoid's parameter, and simply causes the sigmoid to change from 0 to 1 more.

$y$ is defined for a given set of inputs, this information can be combined:

$$
\begin{gathered}
f(w x)=y \\
f(w x)=\sum_{i=1}^{n} w_{i} x_{i} \\
y=\sum_{i=1}^{n} w_{i} x_{i} \\
F(y)=\frac{1}{1+e^{-\alpha y}} \\
F(y)=Y \\
Y=\frac{1}{1+e^{-\alpha \sum_{i=1}^{n} w_{i} x_{i}}}
\end{gathered}
$$

In the training phase, the desired output of the neural network is given.

Therefore, it is possible to define the error as the difference between the desired output and the actual calculated output. If the symbol $T$ is assigned to the target output (either 1 
for bankrupt or 0 for non-bankrupt) and a $j$ subscript is used to denote individual specimens, the error to be adjusted $e$ may be defined as:

$$
e_{j}=Y_{j}-T_{j}
$$

Therefore, the Mean Squared Error (MSE) may be defined as a function of the weights:

$$
E(w)=\frac{1}{2} \sum_{j=1}^{p}\left(Y_{j}-T_{j}\right)^{2}
$$

After carrying out the mathematical steps above, a Mean Squared Error (MSE) is be reached. It is the purpose of the iteration process to adjust these weights in such a way that reduces the Mean Squared Error.

If a certain weight produces a relatively small error, this weight does not need to be changed by the same factor as one which produces a large error. Therefore, by using an optimization algorithm, a local minimum of a function can be found with respect to the weights that were used. This is done mathematically by making adjustments to the weights using the gradient descent method. Using this method weights are changed by the equation:

$$
\Delta w_{i j}=-\eta \frac{\partial E}{\partial w_{i j}}
$$

In this equation, the change in error with respect to the weights is defined as a partial derivative since the error is also a function of the inputs. A new term, $\eta$, is referred to as the "learning factor." This factor may be used to either increase or decrease the amount by which the weights are changed. This will either speed or slow the solution. In some cases, slowing the solution may be necessary in order to provide numerical 
stability. The partial derivative of the error was found by considering the three mathematical steps used to determine:

$$
\begin{aligned}
& E(w): \\
& E(Y) \\
& Y(y) \\
& y(w)
\end{aligned}
$$

Therefore,

$$
E(Y(y(w)))
$$

Expanding the derivative:

$$
\frac{\partial E}{\partial w}=\frac{\partial E}{\partial Y} \frac{\partial Y}{\partial y} \frac{\partial y}{\partial w}
$$

Derivative of $y$ is simply $x$ :

$$
\frac{\partial y}{\partial w}=x
$$

The derivative of the sigmoid is:

$$
\frac{\partial Y}{\partial y}=\alpha y(1-y)
$$

Finally, the algebraic equation for the Mean Squared Error may be differentiated to yield:

$$
\frac{\partial E}{\partial Y}=\sum(Y-T)
$$

Substituting all of these derivatives into the equation for the adjustment of the weights: 


$$
\Delta w_{i j}=\sum\left(Y_{j}-T_{j}\right)\left[\alpha y_{j}\left(1-y_{j}\right)\right] x_{i j}
$$

The weights of the next iteration $(t+1)$ may then be found by:

$$
w_{i j}^{(t+1)}=w_{i j}^{t}+\Delta w_{i j}^{t}
$$

With the ability to adjust the weights in a manner which reduces the Mean Squared Error, it is now possible to construct an iterative algorithm which will arrive at weights that produce minimal error. This process repeats until the error converges to a satisfactory value, which falls below threshold value. This back propagation learning algorithm is summarized in Figure 2. 
Figure 2. Back-propagation Learning Algorithm

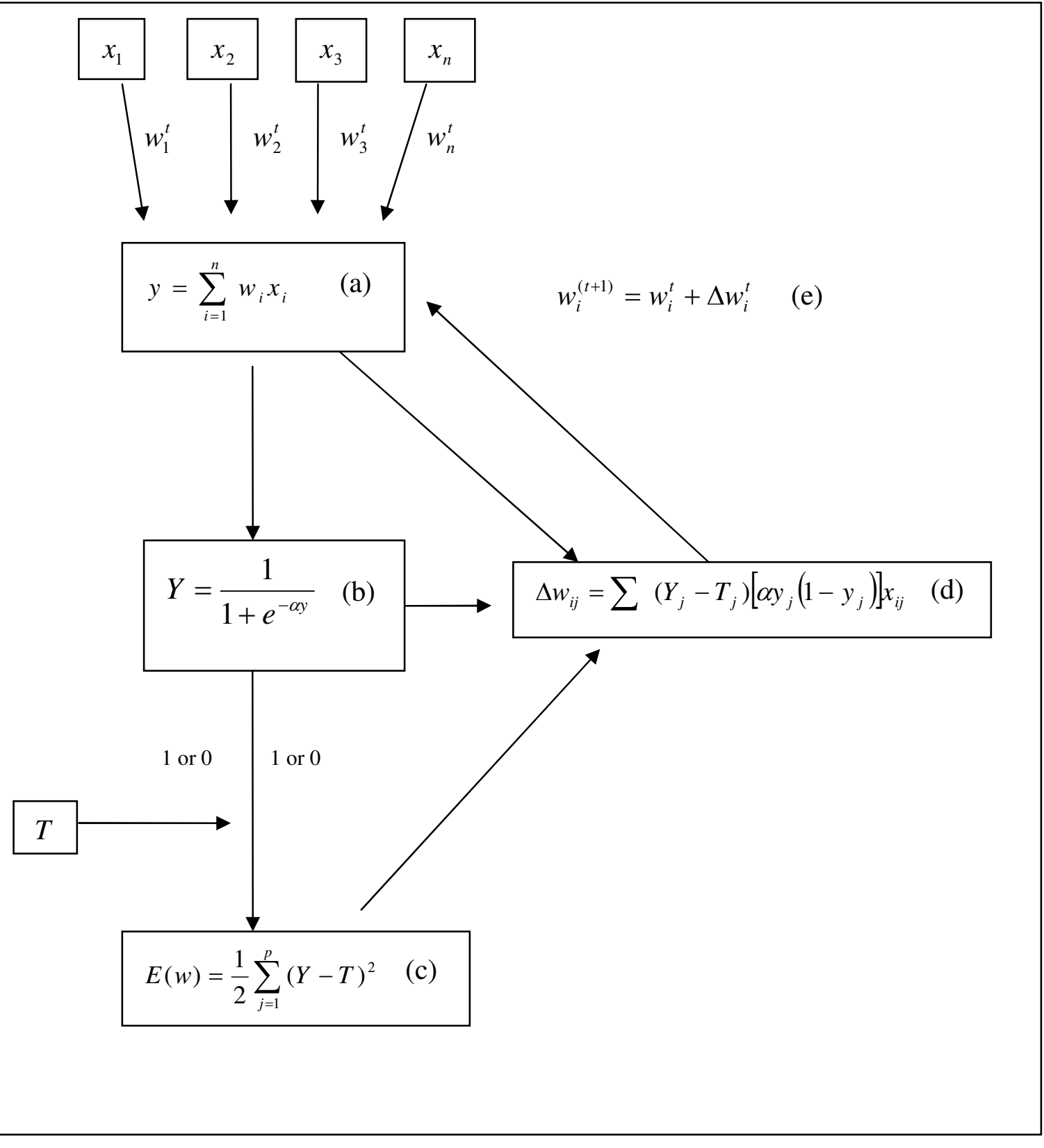

Note: $\chi_{1}, \chi_{2}, \chi_{3}, \chi_{\mathrm{n}}=$ input vectors, $w_{1}^{t}, w_{2}^{t}, w_{3}^{t} w_{n}^{t}=$ varying weights associated with value $\chi, \mathrm{T}=$ the target outputs (either 1 for bankrupt or 0 for non-bankrupt) 
In order to validate the classifying performances of the logit analysis and the neural network analysis, 24 firms excluded in model estimations, consisting of eight bankrupt firms and 16 non-bankrupt firms, were used in out-of-sample test. The estimated model from logit analysis was tested with a holdout sample and the trained neural network model was tested with a testing sample.

Last, the number of firms correctly classified was counted as contrasted to the number of firms incorrectly classified to obtain the accuracy rates from logit and neural network analysis. The accuracy rates of two methodologies were compared to evaluate performances in predicting bankruptcy of hospitality firms. 


\section{CHAPTER IV}

\section{FINDINGS}

\section{Mean Comparison}

\section{Independent sample t-test}

The financial information of bankrupt and non-bankrupt firms represented by 18 ratios was compared. In order to compare the mean value of the two groups, an independent sample t-test was employed. The results of the independent sample t-test show that eight financial ratios were significantly different between the two groups at the 0.10 level: current ratio, quick ratio, working capital to total assets, EBITDA, EBIT to total current assets, debt to market value of equity, return on assets, and net income to the number of employees. Among the eight ratios, five ratios: working capital to total assets, EBITDA, EBIT to total current assets, debt to market value, and net income to the number of employees were likewise significant at the .05 level, showing that there were significant differences in these five ratios between two groups. Table 3 shows each group's mean value of 18 financial ratios, independent t-test value, and p-value. 
Table 3. Comparison of Financial Ratios of the Two Groups

\begin{tabular}{l|cccc}
\hline \multicolumn{1}{c|}{ Ratio } & $\begin{array}{c}\text { Mean } \\
\text { (Bankrupt } \\
\text { Firms) }\end{array}$ & $\begin{array}{c}\text { Mean } \\
\text { (Nonbankrupt } \\
\text { Firms) }\end{array}$ & T-Value & P-Value \\
\hline Current Ratio & .5600 & 1.2287 & -1.962 & $.052^{*}$ \\
Quick Ratio & .3992 & .9779 & -1.682 & $.095^{*}$ \\
Working Capital to Total Assets & -.3250 & -.0462 & -2.999 & $.005^{* *}$ \\
EBITDA & 10.8817 & 191.8539 & -2.898 & $.005^{* *}$ \\
EBIT to Total Current Assets & -.4046 & .3514 & -2.056 & $.042^{* *}$ \\
EBIT to Total Assets & .1458 & .1103 & .288 & .776 \\
Debt to EBITDA & 24.9504 & 5.6363 & 1.185 & .248 \\
Liabilities to Net Worth & 146.3417 & 87.2173 & .522 & .606 \\
Debt to Market Value of Equity & 8.9346 & .6549 & 2.227 & $.036^{* *}$ \\
Tangible Financial Leverage & -1.5808 & 8.6315 & -.755 & .452 \\
Net Income & -11.1300 & 90.2663 & -1.320 & .189 \\
Gross Profit Margin & 30.2000 & 23.1200 & 1.253 & .221 \\
Net Profit Margin & -47.8654 & -7.9851 & -1.317 & .200 \\
Total Asset Turnover & 1.5983 & 1.6371 & -.162 & .871 \\
Fixed Asset Turnover & 2.6254 & 3.9914 & -1.360 & .176 \\
Return on Assets & -.1750 & .0036 & -1.986 & $.058^{*}$ \\
Return on Sales & -.4467 & -.0785 & -1.206 & .239 \\
Net Income to the Number of Employees & -17.6392 & 2.1461 & -2.068 & $.041^{* *}$ \\
\hline Not EBIT=
\end{tabular}

Note: EBIT = earning before interest and tax, EBITDA= earning before interest, tax, and depreciation and amortization *Significant at the .10 level. **Significant at the .05 level.

\section{In-Sample Model Construction}

\section{Estimated Logit Model}

The logistic regression result selected four independent variables and a constant at significance level of 0.05: gross profit margin, EBITDA to total asset, debt to market value of equity, and EBIT to total current assets. Cox \& Snell $\mathrm{R}^{2}$ and Nagelkerke $\mathrm{R}^{2}$ are pseudo-R squares. They show a goodness of fit of regression models. Omnibus test results demonstrated that the overall goodness of the estimated model was significant at 0.01 level associated with 48.257 chi-square value. Hosmer \& Lemeshow Test was not 
significant at 0.05 level. Thus, the null hypothesis that there is no difference between the observed and predicted values of dependent was rejected, indicating the logistic model is a good fit. A value of $(\beta)$ refers to coefficient of variables and constant. A Wald test was used to test the statistical significance of each coefficient $(\beta)$ in the model. Four variables and constant were significant at 0.05 level. Table 4 presents a summary of the estimated Logit model for the hospitality firms' bankruptcy prediction.

Table 4. Summary of the Estimated Logit Model

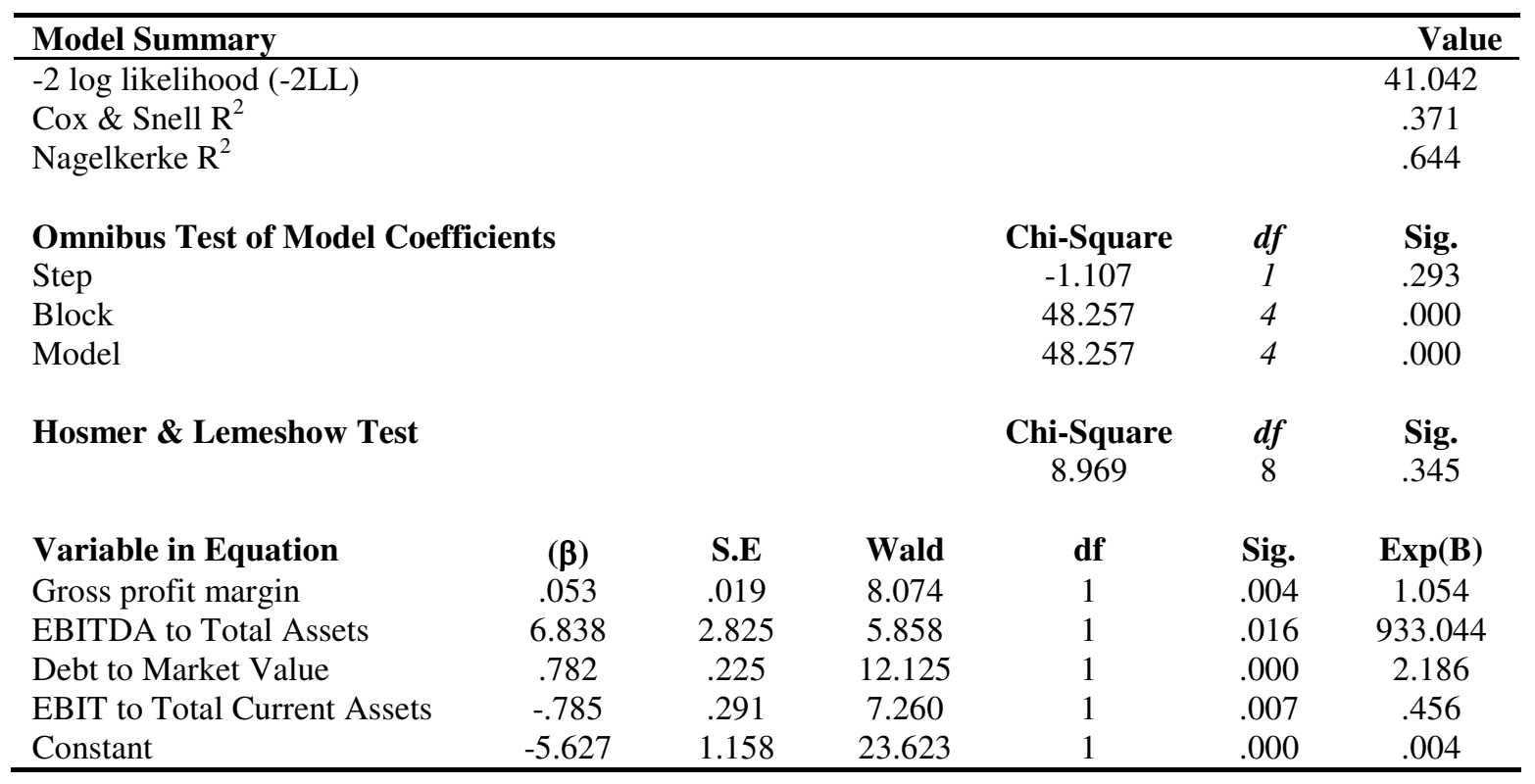

As a result of logit analysis for bankruptcy for the hospitality industry, the estimated logit model used to calculate the probability of bankruptcy was constructed in the manner previously described using the variables: 


$$
\operatorname{Logit}\left[\frac{P(x)}{(1-P(x))}\right]=-5.627+0.053 X_{1}-6.838 X_{2}+.782 X_{3}-.785 X_{4}
$$

Where,

$$
\begin{aligned}
& X_{1}=\text { gross profit margin } \\
& X_{2}=\text { EBITDA to total asset } \\
& X_{3}=\text { debt to market value of equity } \\
& X_{4}=\text { EBIT to total current asset }
\end{aligned}
$$

From this logit analysis, 104 sample firms (16 bankrupt firms and 88 nonbankrupt firms) in analysis were classified into two groups. Firms with predicted probabilities above 0.5 , the cut-off value, were classified as bankrupt and firms with predicted probabilities below 0.5 were classified as non-bankrupt. The estimated model correctly classified 95 firms, showing a 91.3\% overall accuracy rate, or correspondingly, incorrectly classified 9 firms, an $8.7 \%$ overall error rate. A closer look showed that the $8.7 \%$ overall error rate was associated with type-I error, misclassification of failed firms into non-failed firms, as well as type-II error, misclassification of non-failed firms into failed firms. When divided into type-I and type-II errors, it was seen that these were $6.7 \%$ and $1.9 \%$, respectively. Table 5 shows the classification results of the bankruptcy prediction model drawn from two analyses. 
Table 5. Logit Model In-Sample Classification

\begin{tabular}{|c|c|c|c|c|c|}
\hline \multirow{2}{*}{ Actual Status } & \multirow{2}{*}{ Number Cases } & \multicolumn{2}{|c|}{ Predicted Status } & \multirow{2}{*}{$\begin{array}{c}\text { Accuracy } \\
\text { Rate }\end{array}$} & \multirow{2}{*}{$\begin{array}{c}\text { Overall } \\
\text { Accuracy }\end{array}$} \\
\hline & & Bankrupt & N-Bankrupt & & \\
\hline Non-Bankrupt & 88 & 2 & 86 & 97.7 & \multirow{2}{*}{91.3} \\
\hline Bankrupt & 16 & 9 & 7 & 56.3 & \\
\hline
\end{tabular}

\section{Trained Neural Network Model}

After construction of the logit model, the same data were subjected to Clementine using neural network analysis. The model generated 25 neurons in the first hidden layer and 12 neurons in the second hidden layer. The output layer of the neuron took a value of either 1 (bankrupt) or 0 (non-bankrupt) depending on the case. Estimated accuracy of the model was $92.9 \%$. The model selected five inputs depending on each input's contribution in the model training phase. Five inputs: fixed asset turnover, working capital to total assets, debt to market value of equity, liabilities to net worth, and gross profit margin were selected along with a degree of relative importance. Table 6 represents a summary of the trained neural network model. 
Table 6. Summary of the Trained Neural Network Model

\begin{tabular}{|c|c|c|}
\hline Model Summary & & Value \\
\hline Estimated Accuracy & & $92.857 \%$ \\
\hline Input Layer & Hidden Layer 2 & Output Layer \\
\hline 25 neurons & 12 & 1 neurons \\
\hline \multicolumn{3}{|l|}{ Sensitivity Analysis } \\
\hline \multicolumn{3}{|l|}{ Relative Importance of Inputs } \\
\hline Fixed Assets Turnover & & 1.05 \\
\hline Working Capital to Total Assets & & 1.00106 \\
\hline Debt to Market Value of Equity & & 0.987545 \\
\hline Liabilities to Net Worth & & 0.918479 \\
\hline Gross Profit Margin & & 0.548275 \\
\hline
\end{tabular}

Model Validation

\section{$\underline{\text { Hold-out Sample Test }}$}

Each company's predicted probability of going bankrupt was calculated according to Equation 3, which was derived from logistic regression analysis with 104 insample firms. The logistic equation above (3) was transformed into the equivalent formulation below in order to obtain predicted probability of bankruptcy occurrence.

$$
\mathrm{P}(\mathrm{x})=\frac{e^{(-5.627+0.053 \mathrm{X} 1-6.838 \mathrm{X} 2+.782 \mathrm{X} 3-.785 \mathrm{X} 4)}}{1+e^{(-5.627+0.053 \mathrm{X} 1-6.838 \mathrm{X} 2+.782 \mathrm{X} 3-.785 \mathrm{X} 4)}}
$$

Where,

$$
\begin{aligned}
& \mathrm{X}_{1}=\text { gross profit margin } \\
& \mathrm{X}_{2}=\text { EBITDA to total asset } \\
& \mathrm{X}_{3}=\text { debt to market value of equity } \\
& \mathrm{X}_{4}=\text { EBIT to total current asset }
\end{aligned}
$$


Based on Equation (4), the predicted probability of each firm in the holdout sample was obtained, and firms were classified into two groups depending on their predicted probability using a cut-off value 0.5 . Table 7 shows the predicted probability and membership of each firm. As Table 7 demonstrates, 20 out of the 24 firms were classified correctly indicating $83.3 \%$ of overall prediction accuracy. The model failed to place four bankrupt firms into the bankrupt group. This translated into 16.7\% Type-I error. However, this particular model correctly identified all non-bankrupt firms, giving it no associated Type-II error.

Table 7. Holdout Sample Prediction from Logit Model

\begin{tabular}{lccc}
\hline & Actual Group & Predicted Group & P(E) \\
\hline American Restaurant group, inc & 1 & 1 & 0.8569 \\
Buffet Holdings, Inc. & 1 & 1 & 0.8287 \\
Einstein Noah Resaturant & $1^{* *}$ & 0 & 0.0106 \\
ICH & $1^{* *}$ & 0 & 0.2431 \\
Krystal co & $1^{* *}$ & 0 & 0.0028 \\
Piccadilly Cafeterias & $1^{* *}$ & 0 & 0.0031 \\
Planet Hollywood & 1 & 1 & 0.9935 \\
Prandium Inc & 1 & 1 & 0.9485 \\
BJ's Restaurants Inc. & 0 & 0 & 0.0040 \\
Carrols Corp & 0 & 0 & 0.0010 \\
Champps Entertainment Inc. & 0 & 0 & 0.0030 \\
Mortons Restaurant Group Inc & 0 & 0 & 0.0012 \\
Papa Johns International Inc. & 0 & 0 & 0.0020 \\
Texas Roadhouse Inc. & 0 & 0 & 0.0009 \\
Buca Inc. & 0 & 0 & 0.0028 \\
California Pizza Kitchens Inc. & 0 & 0 & 0.0013 \\
Champion Entertainment, Inc & 0 & 0 & 0.0016 \\
Diedrich Coffee Inc. & 0 & 0 & 0.0432 \\
Frisch's Restaurants Inc. & 0 & 0 & 0.0008 \\
Max \& Ermas Restaurants & 0 & 0 & 0.0021 \\
KSL Recreation Group Inc. & 0 & 0 & 0.0049 \\
Starwood Hotels \& Resorts World & 0 & 0 & 0.0050 \\
Sonesta International Hotels & 0 & 0 & 0.1078 \\
Steak N Shake Co. & 0 & 0 & 0.0092 \\
\hline
\end{tabular}

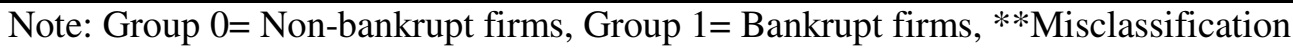




\section{Testing Sample Test}

In the neural network analysis, 24 firms were tested to validate the effectiveness of the trained neural network model. The confidence level simply indicated the degree of likeliness of output predicted by the trained model. As shown below, 21 out of the 24 firms were classified correctly demonstrating $87.5 \%$ overall prediction accuracy. In other words, the model had a12.5\% error rate. This entire error rate was made up of Type-I error, a misclassification of failed firm as non-failed firm. However, it could again be seen that this model produces no Type-II error. Table 8 shows the confidence level of neural network analysis and a final membership of each firm. 
Table 8. Testing Sample Prediction from Neural Network Model

\begin{tabular}{lccc}
\hline & Actual Group & Predicted Group & Confidence \\
\hline American Restaurant group, inc & 1 & 1 & 0.7713 \\
Buffet Holdings, Inc. & 1 & 1 & 0.7713 \\
Einstein Noah Restaurant & $1^{* *}$ & 0 & 0.7950 \\
ICH & 1 & 1 & 0.2757 \\
Krystal co & $1^{* *}$ & 0 & 0.8147 \\
Piccadilly Cafeterias & $1^{* *}$ & 0 & 0.7457 \\
Planet Hollywood & 1 & 1 & 0.7713 \\
Prandium Inc & 1 & 1 & 0.7713 \\
BJ's Restaurants Inc. & 0 & 0 & 0.8588 \\
Carrols Corp & 0 & 0 & 0.8112 \\
Champps Entertainment Inc. & 0 & 0 & 0.8382 \\
Mortons Restaurant Group Inc & 0 & 0 & 0.8112 \\
Papa Johns International Inc. & 0 & 0 & 0.8586 \\
Texas Roadhouse Inc. & 0 & 0 & 0.8112 \\
Buca Inc. & 0 & 0 & 0.8583 \\
California Pizza Kitchens Inc. & 0 & 0 & 0.8589 \\
Champions Inc. & 0 & 0 & 0.8497 \\
Diedrich Coffee Inc. & 0 & 0 & 0.8578 \\
Frisch's Restaurants Inc. & 0 & 0 & 0.8264 \\
Max \& Ermas Restaurants & 0 & 0 & 0.7683 \\
KSL Recreation Group Inc. & 0 & 0 & 0.8112 \\
Starwood Hotels \& Resorts World & 0 & 0 & 0.6871 \\
Sonesta International Hotels & 0 & 0 & 0.5341 \\
Steak N Shake Co. & 0 & 0 & 0.7713 \\
\hline
\end{tabular}

Note: Group $0=$ Non-bankrupt firms, Group 1= Bankrupt firms, **Misclassification 


\section{CHAPTER V}

\section{CONCLUSION}

Summary of the Study

This study compared the accuracy of an Artificial Neural Networks for predicting hospitality firms' bankruptcy occurrences to that of a logit model. The research questions were as follows:

Research Question 1: Does an Artificial Neural Networks outperform Logit, a conventional statistical technique, in predicting a hospitality firm's bankruptcy?

Research Question 2: What financial ratios significantly predict the classification of hospitality firms as bankrupt or non-bankrupt?

To achieve the purpose of study, 128 hospitality firms represented by the primary Standard Industrial Classification (SIC) code 5812 (Eating and Drinking Places), 7011 (Hotels and Motels) and 7990 (Services-Miscellaneous Amusement \& Recreation) were included in the study. Eighteen financial ratios of 128 firms were collected from Standard \& Poor's Compustat database and a total of 2304 input values were analyzed. Analytic techniques of the present study were a logit and an ANNs model. Collected data was imported to SPSS for Logit analysis and Clementine for a neural network analysis. The results of these two analyses were the subject of comparison. 


\section{Discussion and Implications}

This study demonstrated the power of neural network by comparing its predictive capability with that of a logit model in predicting hospitality bankruptcy. From empirical results of the two methodologies, it was shown that neural network obtained a higher accuracy rate than did a logit model in an in-sample test as well as in holdout (testing) sample test. This result confirmed previous assertions made by many researchers stating the superiority of neural network over logit models in classification and prediction tasks.

Neural network analysis showed that the trained neural network model achieved 92.9\% estimated accuracy. This was slightly higher than the accuracy rate achieved by the logit model. In the testing (holdout) sample test, the ANNs model confirmed the validity of the trained model with an $87.5 \%$ accuracy rate associated with $12.5 \%$ Type-I

error and $0.0 \%$ Type-II error. It is noteworthy that not only did neural network achieve a higher overall accuracy rate than the logit model from in-sample test as well as from holdout test, but the higher accuracy rate was attained by lowering Type-I error, that is, lowering the misclassification of failed firms. Since Type-I error involves much higher costs than does Type-II error (Lee et al., 2005), it could be inferred that neural network models are a more sophisticated tool when used for classification tasks than are a logit models.

Second, the empirical results of analyses provided an instrument to take a closer look into companies' financial status. A t-test revealed the underlying structure of 
financial ratios between failed and non-failed firm. As shown in Table III, five ratios: working capital to total assets, EBITDA (earning before interest, tax, and depreciation and amortization), EBIT (earning before interest and tax) to total current assets, debt to market value of equity, and net income to the number of employees, demonstrated significant difference between the two groups. Each ratio measured a certain dimension of companies' financial status depends on contexts it contains. The five ratios found from the analysis belong to sub categories that represent liquidity, solvency, profitability, and efficiency. This implies that bankrupt firms are likely to have less liquidity and solvency to meet their short-term and long-term financial obligations than are non-bankrupt firms. Illiquidity could be caused by insufficient cash due to unprofitable and inefficient operations. Recalling that bankruptcy is defined as the inability of a firm to meet its payment obligations due to a lack of liquidity and solvency, this was no surprise. Although far more factors must be taken into account in order to diagnose a firm's financial position, implications drawn from the t-test could confirm the well-known cause of a company's bankruptcy.

In the estimated logit model, as shown in Table 4, four variables: gross profit margin, EBITDA to total assets, debt to market value of equity, and EBIT to total current asset were selected as significant variables from logit analysis. This does not mean that each of the four ratios provide conclusive evidence when taken individually.Gross profit margin, EBITDA to total assets, debt to market value, and EBIT to total current assets together constitute the most straightforward indicators for predicting bankruptcy in the 
logit model. In a sense of building a logit bankruptcy prediction model, a company's success or failure is a simple outcome of the complex function of inputs summed and transformed together weighing by importance of these four ratios' role.

Although a single ratio from each analysis does not provide conclusive evidence individually in deciding whether a firm goes bankrupt or not, special attention was paid to a ratio 'debt to total market value of equity'. Neural Network's trained model ranked debt to market value of equity as a highly important input in building a bankruptcy prediction model. Debt to market value of equity was a significant variable from both ttest and logit analysis. Debt to market value of equity is a leverage ratio indicating how a business or a firm utilizes debts instead of utilizing equity to maximize its speculative capacity. It is known that utilizing leverage could increase potential profits, gains, and growths. However, it is more important to note that it could amplify losses when investment returns do not meet its expected level, which simply includes, interest and principal payments. The results of the t-test showed that the mean value of debt to market value of equity of bankrupt firms was significantly higher than that of the non-bankrupt firm group, while a positive coefficient of debt to market value of equity in the logit model implied that a higher value of this ratio leads a classification into bankruptcy. Since the hospitality firms are especially well-known for being highly-leveraged, a conclusion could be drawn that extensive debt-financing not accompanied by competitive market value of equity could play a vital role in forcing firms to file for bankruptcy. 
ANNs have received great attention as a tool for classification tasks. Research has revealed the superiority of neural network techniques over logit models. As shown in the results of the present study, the ANNs model achieved higher prediction accuracy than did the logit model when two sets of an identical sample were analyzed. This result could be attributed to neural networks' outstanding prediction accuracy when it carries out classification or prediction tasks. However, every technical methodology has drawbacks, and neural networks are no exception.

ANNs demonstrated a surprisingly accurate predictive ability compared to other techniques. In order to get a good result, extensive data preparation was required. An order and format or data setting can make a big difference in the results and neural networks cannot accommodate missing values. Thus, careful attention is required when preparing data. Moreover, ANNs involve complex mathematical equations, with a lot of transformations and exponential functions, to produce extensive networks in hidden layers, which are not easily understood and interpreted. This is why ANNs is not preferred if one is more concerned with the context of the results than with the results themselves. As the term 'hidden layer' implies, a complex networking inside a model, sometimes, can be obscure to human eyes. If one is simply concerned with the results, as in the case of detecting credit card fraud, a neural network may be the best choice. However, the contexts of such decisions are not quantifiable. A critique of the current study should take this into consideration. 
It was a meaningful finding that a neural network model achieved higher accuracy rate attained by lowering type-I error compared to a logit model. This can be vital information when companies try to protect themselves from going bankrupt by being alerted to trouble early on. However, it was a bit difficult to interpret a network model to draw further implications. The model ranked inputs according to the magnitude of contribution in the model construction process, but it did not tell how inputs behaved inside of the model, whether its impact was positive to the output or negative to the output, whereas the logit model extracted significant variables along with the coefficient values, which allows one to construct a bankruptcy model after such analysis. Although intermediate variables are defined within the network, these parameters are of limited interpretive value and are certainly not comparable statistical values to which they appear analogous. This leaves neural networks open to criticism by researchers who wish to draw implications from the algorithm's convoluted, nonlinear data transformation (Delen \& Sirakaya, 2006; Matheus, Chan, \& Piathtsky-Shapiro, 1993). A neural network is a great detection tool, which will reveal whether an event will occur or not, however, further investigation is required. No technique is perfect for all situations. It can be thus concluded that a technical approach should be accompanied by an awareness of the strengths and weaknesses of each technique in order to obtain the best result with regard to its implication. 


\section{Limitations and Future Research}

This study was not free of limitations. The small sample size, due to the lack of available financial data, precluded more sophisticated analysis. Despite an attempt to match bankrupt and non-bankrupt firms according to asset size and year of bankruptcy to minimize such limitations, such a data set could not be generated due to this study's focus on the hospitality industry.

For the same reason, this study could test only one year prior to bankruptcy. A one year period is not long enough for managers to make strategic plans for recovery. An early warning sign of bankruptcy could allow hospitality firms times to restructure the organization or debt-financing policies to prevent themselves from filing for bankruptcy.

In addition, the study analyzed business failure only from an internal perspective. Business entities interact with society and are affected by factors such as politics, economics, and culture. Hospitality firms are especially vulnerable to social and economic changes since the majority of revenue relies on disposable income. It is difficult for a social phenomenon to be explained by a single factor and from a single perspective. Therefore, it is recommended to take external aspects into account when analyzing hospitality bankruptcy.

These limitations suggest avenues for further research. First, a longer period of observation can be conducted in order to draw more practical implication. Investigation for bankruptcy occurrences can be conducted two years, five years, or even 10 year prior to bankruptcy in maximize the efficacy of prediction tools. To ensure comparability and 
minimize effects of factors not being addressed by the study, matching the bankrupt and non-bankrupt groups' asset size and year of bankruptcy is recommended. In particular, this could give researchers the possibility of using a more sophisticated analysis, which may result in more accurate observations.

Second, it is suggested that a study using another advanced techniques such as Support Vector Machine (SVM), genetic algorithms, or data envelopment analysis. These methods have recently been tested by many scholars and researchers and the outstanding capabilities of these methods have been proven. Thus, it is expected that using these technique will generate even more robust results.

\section{REFERENCES}


Altman, E. I. (1968). Financial ratios, discriminant analysis and the prediction of corporate bankruptcy. Journal of Finance ,23(4), 589-609.

Altman, E. I. (1993). Corporate Financial Distress and Bankruptcy - A complete guide to predicting \& avoiding distress and profiting from bankruptcy. New York: John Wiley \& Sons, Inc.

Altman, E. I., Marco, G., \& Varetto, F. (1994). Corporate distress diagnosis: Comparisons using linear discriminant analysis and neural networks (the Italian experience). Journal of Banking and Finance, 18, 505-529.

Aminian, F., Suarez, D.D., Aminian, M., \& Walz, D. T. (2006). Forecasting economic data with neural networks. Computational Economics, 28, 71-88.

Anandarajan, M., Lee, P., \& Anandarajan, A. (2001). Bankruptcy prediction of financially stressed firms: An examination of the predictive accuracy of artificial neural networks. International Journal of Intelligent Systems in Accounting, Finance and Management, 10(2), 69-81.

Andrew, W. P., \& Schmidgall, R. S. (1993). Financial Management for the Hospitality Industry. Michigan, The Educational Institute of the American Hotel \& Lodging Educational Institute.

Angelo, R. M., \& Vladimir, A. N. (2001). Hospitality Today. 4th ed. Michigan, The Educational Institute of the American Hotel \& Lodging Educational Institute. 
Baesens, B., Setiono, R., Mues, C., \& Vanthienen, J. (2003). Using neural network rule extraction and decision tables for credit-risk evaluation. Management Science, 49(3), 312-329.

Barniv, R., Agarwal, A., \& Leach, R.(2002). Predicting bankruptcy resolution. Journal of Business Finance \& Accounting, 29(3), 497-520.

Belhadjali, M., \& Whaley, G. L. (2004). A data mining approach to neural network training. Information Management \& Computer Security, 12(1), 117-124.

Beaver, W. H. (1968). Market prices, financial ratios, and the prediction of failure. Journal of Accounting Research, 6(2), 179-192.

Blum, M. (1974). Failing company discriminant analysis. Journal of Accounting Research, 12(1), 1-25.

Boritz, J. E., \& Kennedy, D. B. (1995). Effectiveness of neural network types for prediction of business failure. Expert System with Application, 9(4), 503-512.

Chava, S., \& Jarrow, R. A. (2004). Bankruptcy prediction with industry effects. Review of Finance, 8, 537-569.

Cho, V. (2003). A comparison of three different approaches to tourist arrival forecasting. Tourism Management, 24, 323-330.

Chi, L., \& Tang, T. (2006). Bankruptcy prediction: Application logit analysis in export credit risk. Australian Journal or Management, 31(1), 17-27.

Coats, P. K., \& Fant, L. F. (1993). Recognizing financial distress patterns using a neural network tool. Financial Management,142-155. 
Darayseh, M., Waples, E., \& Tsoukalas, D. (2003). Corporate failure for manufacturing industries using firms specifics and economic environment with logit analysis. Managerial Finance, 29(18), 23-36.

De Carvalho, M., Dougherty, M., Fowkes, A., \& Wardman, M. (1998). Forecasting travel demand: a comparison of logit and artificial neural network methods. Journal of the Operational Research Society, 49, 717-722.

Delen, D., \& Sirakaya, E. (2006). Determining the efficacy of data-mining methods in predicting gaming ballot outcomes. Journal of Hospitality \& Tourism Research, 30(30), 313-332.

Dimitras, A. I., Zanakis, S.H., \& Zopounidis, C. (1996). A survey of business failures with an emphasis on prediction methods and industrial applications. European Journal of Operational Research, 90, 487-513.

Edmister, R. O. (1972). An empirical test of financial ratio analysis for small business failure prediction. Journal of Financial and Quantitative Analysis, 7, 1477-1493.

Elgonemy, A. R. (2002). Debt-financing alternatives: Refinancing and restructuring in the lodging industry. Cornell Hotel and Restaurant Administration Quarterly, 43(3), 7-21.

Ernist, S. (2002). Market analysis, financial plan improve restaurants' success. Hotel and Motel Management, 217(8), 10.

Ferner, D. G., \& Hamilton, R. T. (1987). A note on the predictability of financial distress in New Zealand listed companies. Accounting and Finance, 27(1), 55-63. 
Gao, L. (1999). Study of Business Failure in the Hospitality Industry from both Microeconomic and Macroeconomic Perspectives. Unpublished Masters Thesis, University of Nevada, Las Vegas, United States.

Gu, Z. (2002). Analyzing bankruptcy in the restaurant industry: A multiple discriminant model. International Journal of Hospitality Management, 21, 25-42.

Gu, Z. \& Gao, L. (1999). A multivariate model for predicting business failures of hospitality firms. Tourism and Hospitality Research, 2(1), 37-49.

Hamer, M. M. (1983). Failure prediction: sensitivity of classification accuracy to alternative statistical methods and variable sets. Journal of Accounting and Public Policy, 2, 289-307.

Harris, P. J., \& Brown, J. B. (1998). Research and development in hospitality accounting and financial management. International Journal of Hospitality Management, 17, $161-181$.

Hosmer, D. N., \& Lemeshow, S. (1989). Applied Logistic Regression, Wiley, New York.

Keown, A. J., Martin, J. D., Petty, W., \& Scott, Jr, D. F. (1982). Basic Financial Management, 2nd ed. Englewood, NJ: Prenctice-Hall International.

Kim, H. (2006). A logistic regression analysis for predicting bankruptcy in the hospitality industry. The Journal of Hospitality Financial Management, 14(1), 17-34.

Kim, H., \& Gu, Z. (2006). Predicting restaurant bankruptcy: A Logit model in comparison with a discriminant model. Journal of Hospitality \& Tourism Research, 30(4), 474-493. 
Kim, Y., Street, W. N., Russel, G. J., \& Menczer, F. (2005). Customer targeting: A neural network approach guided by genetic algorithms. Management Science, 51(2), 264-276.

Kroeze, C. (2005). Predicting Airline Corporate Bankruptcies Using a Modified Altman Z-Score Model. Unpublished Doctoral Dissertation, University of Nevada, Las Vegas, United States.

Law, R., \& Au, N. (1999). A neural network model to forecast Japanese demand for travel to Hong Kong. Tourism Management, 20, 89-97.

Lee K., Booth, D., \& Alam, P. (2005). A comparison of supervised and unsupervised neural networks in predicting bankruptcy of Korean firms. Expert Systems with Applications, 29, 1-16.

Lo, A. W. (1986). Logit versus discriminant analysis. Journal of Econometrics, 31, 151178.

Matheus, C. J., Chan, P. K., \& Piatetsky-Shapiro, G. (1993). Systems for knowledge discovery in databases. IEEE Transactions on Knowledge and Data Engineering, 5(6), 903-913.

McCulloch, W. S., \& Pitts, W. (1943). A logical calculus of the ideas immanent in nervous activity. Bulletin of Mathematical Biophysics, 5, 115-133.

Minsky, M., \& Paper, S. (1969). Perceptrons. MIT Press, MA. 
Nam, J. \& Jinn, T. (2000). Bankruptcy prediction: Evidence from Korean listed companies during the IMF crisis. Journal of International Financial Management and Accounting, 11(3), 178-197.

Odom, M. D., \& Sharda, R. (1990). A neural network model for bankruptcy prediction. In Proceedings of the IEEE international conference on Neural Networks, 163168.

Ohlson, J. A. (1980). Financial ratios and the probabilistic prediction of bankruptcy. Journal of Accounting Research, 18(1), 109-131.

Palmer, A., Montano, J. J., \& Sese. A. (2003). Designing an artificial neural network for forecasting tourism. Tourism management, 27, 781-790.

Pampel, F. C. (2000). Logistic Regression: A Premier. Sage, Thousand Oaks, CA.

Parsa, H. G., Self, J. T., Njite, D., and King, T. (2005). Why restaurants fail. Cornell Hotel and Restaurant Administration Quarterly, 46(3), 304-322.

Patterson, D. W. (2001). Bankruptcy prediction: A model for the casino industry. Unpublished Doctoral Dissertation, University of Nevada, Las Vegas, United States.

Pattie, D. C., \& Snyder, J. (1996). Using a neural network to forecast visitor behavior. Annals of Tourism Research, 23(1), 151-164.

Rushmore, S. (1992). The valuation of distressed hotels. Cornell Hotel and Restaurant Administration Quarterly, 33(5), 61-71. 
Salchenberger, L. M., Cinar, E. M., \& Lash, N. A. (1992). Neural networks: A new tool for predicting thrift failures. Decision Sciences, 23(4), 899-916.

Shah, J. R., \& Murtaza, M. B. (2000). A neural network based clustering procedure for bankruptcy prediction. American Business Review, 18(2), 80-73.

Sharda, R., \& Wang, J. (1996). Neural networks and operations research/management science. European Journal of Operational Research, 227-229.

Smith, R. A., \& Lesure, J. D. (2004). Barometer of hotel room revenue: A regular service of smith travel research. Cornell Hotel and Restaurant Administration Quarterly, 45(3), 220.

Smith, R. A., \& Lesure, J. D. (2005). Barometer of hotel room revenue: A regular service of smith travel research. Cornell Hotel and Restaurant Administration Quarterly, $46(2), 115$.

Smith, R. A., \& Lesure, J. D. (2006). Barometer of hotel room revenue: A regular service of smith travel research. Cornell Hotel and Restaurant Administration Quarterly, 47(2), 105.

Stavrou, E. T., Charalambous, C., \& Spiliotis, S. (2007). Human resource management and performance: A neural network analysis. European Journal of Operational Research, 181, 453-467.

Tam, K. (1991). Neural network models and the prediction of bank bankruptcy. Omega International Journal of Management Science, 19(5), 429-445. 
Tam, K., \& Kiang, M. Y. (1992). Managerial applications of neural networks: The case of bank failure predictions. Management Science, 38(7), 926-947.

Theodossiou, P. (1991). Alternative models for assessing the financial condition of business in Greece. Journal of Business Finance \& Accounting, 18(5), 697-720.

Tsaur, S., Chiu, Y., \& Huang, C. (2002). Determinants of guest loyalty to international tourist hotels- a neural network approach. Tourism Management, 23, 397-405.

Tseng, F., \& Lin, L. (2005). A quadratic interval logit model for forecasting bankruptcy. International Journal of Management Science, 33, 85-91.

Wang, C. H. (2004). Predicting tourism demand using fuzzy time series and hybrid grey theory. Tourism Management, 25, 367-374.

Wilson, R. L., \& Sharda, R. (1994). Bankruptcy prediction using neural networks. Decision Support Systems, 11, 545-557.

Zavgren, C. V. (1985). Assessing the vulnerability to failure of American industry firms: A logistic analysis. Journal of Business Finance \& Accounting, 12(1), 19-45. 
APPENDIXES 
APPENDIX A

SAMPLE FIRMS USED IN MODEL ESTIMATION 
Sample Bankrupt Hospitality Firms Used in Model Estimation

\begin{tabular}{clr}
\hline IDENTIFICATION & \multicolumn{1}{c}{ BANKRUPT FIRM } & $\begin{array}{c}\text { TOTAL ASSETS } \\
\text { (MILLION \$) }\end{array}$ \\
\hline 9 & ROADHOUS GRILL & 100.33 \\
\hline 10 & TAJ MAHAL & 25.11 \\
\hline 11 & SCHOLATZSKY'S & 125.79 \\
\hline 12 & STEAKHOUS PARTNERS & 32.71 \\
\hline 13 & LODGIAN, INC & 1163.95 \\
\hline 14 & PRIME MOTOR INN, INC. & 122.28 \\
\hline 15 & ARLINGTON HOSTPITALIY, INC & 103.36 \\
\hline 16 & INTEGRA- A HOTEL \& RESORT & 67.01 \\
\hline 17 & HOLLYWOOD CASINO SHREVEPORT & 141.71 \\
\hline 18 & CCI GROUP & 6.19 \\
\hline 19 & CLARIDGE HOTEL\&CASINO & 131.78 \\
\hline 20 & AMERICAN WAGERING INC & 8.94 \\
\hline 21 & FITZGERALDS GAMING CORP & 206.80 \\
\hline 22 & GB HOLDINGS INC & 216.96 \\
\hline 23 & PREMIER EXHIBITIONS INC & 10.76 \\
\hline 24 & WINDSOR WOODMNT BLK HWK REST & 152.93 \\
\hline
\end{tabular}

Note: Identification number was randomly assigned from 1 to 128 to each sample for convenience.

Sample Non-Bankrupt Hospitality Firms Used in Model Estimation

\begin{tabular}{rlr}
\hline IDENTIFICATION & \multicolumn{1}{c}{ NON-BANKRUPT FIRM } & $\begin{array}{c}\text { TOTAL ASSETS } \\
\text { (MILLION \$) }\end{array}$ \\
\hline 41 & GREAT WOLF RESORTS INC & 173.49 \\
\hline 42 & PISMO COAST VILLAGE INC & 8.48 \\
\hline 43 & PANERA BREAD CO & 153.62 \\
\hline 44 & ARK RESTAURANTS CORP & 43.63 \\
\hline 45 & BENIHANA INC -CL A & 204.29 \\
\hline 46 & BERTUCCI'S CORP & 125.20 \\
\hline 47 & BOB EVANS FARMS & 1196.96 \\
\hline 48 & BRAZIL FAST FOOD CORP & 21.95 \\
\hline 49 & BRINKER INTL INC & 2221.78 \\
\hline 50 & BURGER KING HOLDINGS INC & 2552.00 \\
\hline 51 & BUFFALO WILD WINGS INC & 161.18 \\
\hline 52 & CALA CORP & 0.86 \\
\hline 53 & CARIBOU COFFEE CO & 136.31 \\
\hline 54 & CARROLS RESTAURANT GROUP INC & 452.86 \\
\hline 55 & CBRL GROUP INC & 1681.30 \\
\hline 56 & CEC ENTERTAINMENT INC & 704.18 \\
\hline 57 & CHAMPPS ENTMT INC & 332.37 \\
\hline 58 & CHEESECAKE FACTORY INC & 1039.73 \\
\hline 59 & CHIPOTLE MEXICAN GRILL INC & 604.21 \\
\hline 60 & CKE RESTAURANTS INC & 794.422 \\
\hline
\end{tabular}




\begin{tabular}{|c|c|c|}
\hline IDENTIFICATION & BANKRUPT FIRM & $\begin{array}{l}\text { TOTAL ASSETS } \\
\text { (MILLION \$) }\end{array}$ \\
\hline 61 & COSI INC & 75.76 \\
\hline 62 & DARDEN RESTAURANTS INC & 2880.80 \\
\hline 63 & DENNYS CORP & 443.91 \\
\hline 64 & DOMINO'S PIZZA INC & 380.20 \\
\hline 65 & EAT AT JOES LTD & 1.16 \\
\hline 66 & ELEPHANT \& CASTLE & 16.97 \\
\hline 67 & ELXSI CORP & 74.31 \\
\hline 68 & FAMOUS DAVES OF AMERICA INC & 65.64 \\
\hline 69 & FLANIGANS ENTERPRISES INC & 27.40 \\
\hline 70 & FOG CUTTER CAPITAL GROUP INC & 59.80 \\
\hline 71 & FRIENDLY ICE CREAM CORP & 220.17 \\
\hline 72 & GOOD TIMES RESTAURANTS INC & 10.69 \\
\hline 73 & GORDON BIERSCH BRWY RST-REDH & 70.89 \\
\hline 74 & GRANITE CITY FOOD \& BREWERY & 63.86 \\
\hline 75 & GRILL CONCEPTS INC & 32.24 \\
\hline 76 & J. ALEXANDER'S CORP & 99.35 \\
\hline 77 & JACK IN THE BOX INC & 1520.46 \\
\hline 78 & JAMBA INC & 467.55 \\
\hline 79 & KONA GRILL INC & 58.80 \\
\hline 80 & LANDRYS RESTAURANTS INC & 1612.58 \\
\hline 81 & LUBYS INC & 206.75 \\
\hline 82 & MCCORMICK \& SCHMICKS SEAFOOD & 228.42 \\
\hline 83 & MCDONALD'S CORP & 29023.80 \\
\hline 84 & MERITAGE HOSPITALITY GROUP & 46.72 \\
\hline 85 & MEXICAN RESTAURANTS INC & 33.28 \\
\hline 86 & MORGANS FOODS INC & 52.32 \\
\hline 87 & NATHAN'S FAMOUS INC & 46.58 \\
\hline 88 & NUTRITION MGMT SVCS -CL A & 13.97 \\
\hline 89 & O'CHARLEY'S INC & 686.51 \\
\hline 90 & ORGANIC TO GO FOOD CORP & 5.28 \\
\hline 91 & OSI RESTAURANT PARTNERS INC & 2258.59 \\
\hline 92 & P F CHANGS CHINA BISTRO INC & 514.04 \\
\hline 93 & PANERA BREAD CO & 542.61 \\
\hline 94 & PAPA JOHNS INTERNATIONAL INC & 379.64 \\
\hline 95 & PERKINS \& MARIE CALLENDERS & 352.14 \\
\hline 96 & RARE HOSPITALITY INTL INC & 695.21 \\
\hline 97 & RED ROBIN GOURMET BURGERS & 450.60 \\
\hline 98 & ROADHOUSE GRILL INC & 25.11 \\
\hline 99 & RUBIO'S RESTAURANTS INC & 67.50 \\
\hline 100 & RUBY TUESDAY INC & 1171.57 \\
\hline 101 & RUTHS CHRIS STEAK HOUSE & 209.72 \\
\hline 102 & SBARRO INC & 388.54 \\
\hline 103 & SHELLS SEAFOOD RESTRNTS INC & 13.84 \\
\hline 104 & SIXX HOLDINGS INC & 3.47 \\
\hline
\end{tabular}




\begin{tabular}{rlr}
\hline IDENTIFICATION & \multicolumn{1}{c}{ BANKRUPT FIRM } & $\begin{array}{r}\text { TOTAL ASSETS } \\
\text { (MILLION \$) }\end{array}$ \\
\hline 105 & SMITH \& WOLLENSKY RSTRNT GRP & 86.75 \\
\hline 106 & SODEXHO ALLIANCE SA -ADR & 10636.10 \\
\hline 107 & SONIC CORP & 638.02 \\
\hline 108 & SPEEDUS CORP & 17.14 \\
\hline 109 & STAR BUFFET INC & 34.17 \\
\hline 110 & STARBUCKS CORP & 4428.94 \\
\hline 111 & STEN CORP & 10.02 \\
\hline 112 & SYNDICATED FOOD SERVICE INTL & 9.30 \\
\hline 113 & TIM HORTONS INC & 1497.59 \\
\hline 114 & TULLYS COFFE CORP -REDH & 21.53 \\
\hline 115 & VICORP RESTAURANTS INC & 395.24 \\
\hline 116 & VOLUME SERVICES AMERICA INC & 280.19 \\
\hline 117 & WENDY'S INTERNATIONAL INC & 2060.35 \\
\hline 118 & WESTERN SIZZLIN CORP & 19.82 \\
\hline 119 & YUM BRANDS INC & 6353.00 \\
\hline 120 & CHOCTAW RESORT DEV ENTRPRISE & 489.97 \\
\hline 121 & GAYLORD ENTERTAINMENT CO & 2632.52 \\
\hline 122 & HILTON HOTELS CORP & 16481.00 \\
\hline 123 & HOME INNS \& HOTELS MNGT -ADR & 169.14 \\
\hline 124 & INTERCONTINENTAL HOTELS -ADR & 3707.63 \\
\hline 125 & INTERSTATE HOTELS \& RESORTS & 333.69 \\
\hline 126 & MARRIOTT INTL INC & 8588.00 \\
\hline 127 & ORIENT-EXPRESS HOTELS & 1751.66 \\
\hline 128 & RED LION HOTELS CORP & 351.44 \\
\hline
\end{tabular}

Note: Identification number was randomly assigned from 1 to 128 to each sample for convenience. 
APPENDIX B

\section{HOLDOUT FIRMS USED FOR PREDICTION ACCURACY TEST}


Sample Bankrupt Hospitality Firms Used in Accuracy Test

\begin{tabular}{clc}
\hline IDENTIFICATION & \multicolumn{1}{c}{ BANKRUPT FIRM } & $\begin{array}{c}\text { TOTAL ASSETS (MILLION } \\
\mathbf{\$} \text { ) }\end{array}$ \\
\hline & AMERICAN RESTAURANT & 72.82 \\
\hline 1 & GROUP, INC & 538.50 \\
\hline 2 & BUFFET HOLDINGS, INC. & 44.03 \\
\hline 3 & EINSTEIN NOAH RESTAUTANT & 120.42 \\
\hline 4 & ICH & 130.79 \\
\hline 5 & KRYSTAL CO. & 133.70 \\
\hline 6 & PICCADILLY CAFETERIAS & 146.21 \\
\hline 7 & PLANET HOLLYWOOD & 173.88 \\
\hline 8 & PRANDIUM INC. &
\end{tabular}

Note: Identification number was randomly assigned from 1 to 128 to each sample for convenience.

Sample Non-Bankrupt Hospitality Firms Used in Accuracy Test

\begin{tabular}{clr}
\hline IDENTIFICATION & \multicolumn{1}{c}{ NON- BANKRUPT FIRM } & TOTAL ASSETS (MILLION \$) \\
\hline 25 & BJ'S RESTAURANTS INC & 83.71 \\
\hline 26 & CARROLS CORP & 452.86 \\
\hline 27 & CHAMPPS ENTMT INC & 67.09 \\
\hline 28 & MORTONS RESTAURANT GROUP & 124.41 \\
\hline & INC & 128.82 \\
\hline 39 & PAPA JOHNS INTERNATIONAL & 128.53 \\
\hline 30 & INC & 123.44 \\
\hline 31 & TEXAS ROADHOUSE INC & 145.34 \\
\hline 32 & BUCA INC & 79.46 \\
\hline 33 & CALIFORNIA PIZZA KITCHEN & 34.13 \\
\hline 34 & INC & 138.64 \\
\hline 35 & CHAMPPS ENTMT INC & 54.93 \\
\hline 36 & DIEDRICH COFFEE INC & 1034.46 \\
\hline 37 & FRISCH'S RESTAURANTS INC & 263.41 \\
\hline 38 & MAX \& ERMAS RESTAURANTS & 109.54 \\
\hline 39 & KSL RECREATION GROUP INC & 64.14 \\
\hline 40 & STARWOOD HOTELS\&RESORTS \\
\hline
\end{tabular}

Note: Identification number was randomly assigned from 1 to 128 to each sample for convenience. 
VITA

Soo-Seon Park

Candidate for the Degree of

Master of Science

Thesis: A COMPARATIVE STUDY OF LOGIT AND ARTIFICIAL NEURAL NETWWORKS IN PREDICTING BANKRUPTCY IN THE HOSPITALITY INDUSTRY

Major Field: Hotel and Restaurant Administration

Biographical:

Personal Data: Born in Ku-mi, Korea, On May 1, 1982 the second daughter of Myung-Ho Park and Heon-Ja Woo.

Education: Graduated from Eun-Kwang Girls' High School, Seoul, Korea, in February 2001; received Bachelor of Science degree in Hospitality Management from Oklahoma State University, Stillwater, Oklahoma, in December, 2005; Completed the requirements for the Master of Science in Hospitality at Oklahoma State University, Stillwater, Oklahoma in May, 2008.

Experience: Internship, SamSung Everland in Seoul, 2004; Internship, Tan-Tar-a Resort in Osage Beach, Missouri, 2005; Graduate Assistant, University Dining Services, Oklahoma State University, 2006-Present.

Professional Memberships: Member, International Council on Hotel, Restaurant, and Institutional Education, 2007-Present; Vice President, National Society of Minorities in Hospitality, 2006-Present; Member, Club Managers of American Association, 2004-2005

Certificate: English Speaker of English as a second language (ESL), Jan, 2008 
Title of Study: A COMPARATIVE STUDY OF LOGIT AND ARTIFICIAL NEURAL NETWWORKS IN PREDICTING BANKRUPTCY IN THE HOSPITALITY INDUSTRY

Pages in Study: 67

Candidate for the Degree of Master of Science

Major Field: Hospitality

Scope and Method of Study: The hospitality industry has been received scrutiny by many researchers because of its unique characteristics such as fluctuating supply-demand chain, seasonality, and high level of leverage. This is why much research has been conducted to find the best tool for early warning of bankruptcy. Artificial Neural Networks (ANNs) have received a great deal of attention in the area of decision support system because of their outstanding ability to forecast and classify events to make a decision This study employed Artificial Neural Networks (ANNs) to predict bankruptcy among hospitality firms and compared the performance of ANNs in predicting hospitality firms' bankruptcy to the more conventional statistical logit model.

Findings and Conclusions: From empirical results of the two methodologies, it was shown that neural network obtained a higher accuracy rate than did a logit model in an in-sample test as well as in holdout (testing) sample test. This result confirmed previous assertions made by many researchers stating the superiority of neural network over logit models in classification and prediction tasks. Even though ANNs achieved the higher prediction accuracy, they do not provide the user with useful information about how the model arrives at this prediction. Therefore, it is recommended that those who utilize such predictive tools be aware of advantages and disadvantages of the tools being used. 